Article

\title{
Land Access, Agricultural Land Use Changes and Narratives about Land Degradation in the Savannahs of Northeast Ghana during the Pre-Colonial and Colonial Periods
}

\author{
Peter Kojo Boateng \\ Centre for Geography and Environmental Science, Monash University, Melbourne 3800, Australia; \\ peter.boateng@monash.edu; Tel.: +61-450-667-373 \\ Academic Editor: Martin J. Bull \\ Received: 29 December 2016; Accepted: 14 March 2017; Published: 20 March 2017
}

\begin{abstract}
This paper discusses the evolution of socio-cultural and political relations that defined access to, use, and management of land resources in northeast Ghana during the pre-colonial and colonial periods. The aim is to historicise current meta-narratives about degradation of the natural landscape in the rural savannahs of northeast Ghana. Many of those degradation narratives take their root in the past during the colonial era, but the conceptual underpinnings of those narratives have remained essentially a-historical, a-political, and a-cultural. This paper shows that the organisation of space and land uses in pre-colonial communities in northeast Ghana was governed by certain traditional knowledge systems which were ignored by the colonial authorities. While narratives about landscape degradation by natives were propagated by the colonial government to justify a need to preserve the environment, their attempts to control land management matters were essentially for political and economic reasons. The study concludes that current policy frameworks on desertification and land management need to move beyond inherent historical biases. Rather, attention ought to be given to critical historical reflections on the dynamic processes by which variations in socio-economic relations of resource access/use, farming practices, land tenure arrangements, and political agendas interact with changes in the biophysical environment to produce different land cover trajectories over time.
\end{abstract}

Keywords: land degradation; desertification; Northeast Ghana; land use; narratives; politics

\section{Introduction}

Current meta-narratives about land degradation and poor agricultural productivity in the savannah regions of northeast Ghana take their root in the past, but many of those narratives are propagated in the absence of historical memory. Using Malthusian crisis narratives, those perspectives have assumed an always positive relationship between population growth, human access to land resources and land degradation, although the theoretical underpinnings of many of those narratives have remained essentially a-historical, a-political, and a-cultural [1]. Ghana is one of the West African parties to the United Nations Convention to Combat Drought and Desertification (UNCDD). The UNCDD provides technical and financial support for member countries to develop and implement national action plans to combat the effects of droughts and threats of desertification. The Ghana National Action Plan to Combat Drought and Desertification (Ghana NAP hereafter) reports that desertification is creeping southwards from the north of the country at an estimated rate of 20,000 hectares per year, with the attendant destruction of farmlands and livelihoods. It identifies socio-economic (human-induced) factors such as 'population pressure, unsustainable cultivation practices, deforestation, overgrazing, bushfires, 
improper use of agro-chemicals, mining, soil nutrient depletion without replenishment, lack of security in land tenure, migration and poverty' as the major causes of land degradation and desertification in the semi-arid regions of northeast Ghana ([2], p. 16). The plan outlines a number of strategies to address the 'indigenous degradation' of woodland and grassland resources ([2], p. 13). Nowhere in the Action Plan, and indeed in many other desertification studies focussed on the region [3-6] is considerable attention given to historical understanding of the origins of the 'indigenous degradation narratives, the transformations in the socio-economic and political environment of the savannahs of northeast Ghana, and how land use and livelihood systems have adjusted to those transformations.

The aim of this paper is to historicise the evolution of contemporary patterns of land use, land cover and settlements in northeast Ghana from the pre-colonial period (before 1874) up to the colonial period (between 1874 and 1957). The paper discusses the evolution of and changes in socio-cultural and political relations that defined access to, use, and management of land resources. In so doing, this paper traces the trajectories of not only the physical and material aspects of the ever-changing relationships between human communities and their physical environment they live in, but also the conceptual/knowledge systems that people used to define techniques for managing, changing and adapting to the environment [7].

The paper seeks to establish that the organization of space and land uses in pre-colonial communities in northeast Ghana were governed by certain traditional knowledge systems which were ignored by the colonial authorities in their conceptions of environmental change and how to manage land resources to the benefit of the colonial enterprise. Claims about gross degradation of a denser vegetation cover by indigenous communities desperate to meet their immediate food and shelter needs were made by the British colonial government, necessitating the need for imposition of environmental 'conservationist' and agricultural 'productionist' measures that drastically transformed the organisation of space in northeast Ghana. In the analyses, I question some of the bases used for those indigenous degradation claims_claims such as existing forest islands being remnants of a former densely vegetated landscape-and analyse the changes in land tenure and organisation of space as a result of the activities of the British colonial government.

After the introduction and discussion on the study area and methods used, the rest of the paper is organised into two main parts. The first part covers the pre-colonial period, beginning with discussions on the historical origins of three tribes of peoples found in the study areas of this research-the Guruse-Frafra people, the Kassena people, and the Kusasi people. I provide accounts of, among others, their origins and journeys to their present location, their early social and political organisation, and finally relate these histories to how they may have organised agricultural land use and their natural environment. Part II of this paper then relates these historical accounts to the early colonial environmental discourses and conceptualisations of natural resource management in the northeast savannah region.

\section{Study Area Context}

Ghana spans several climatic zones, from the tropics in the south to the semi-arid Sahel region in the far north of the country. The northeast savannah agro-ecosystem covers about 8842 square $\mathrm{km}$, which translates into $2.7 \%$ of the total land area of the country [8]. The natural vegetation is that of the (Guinea) savannah woodland characterised by fire tolerant, deciduous, broad-leaved trees interspersed in a ground flora of mainly grass, sometimes more than $1.5 \mathrm{~m}$ high [9]. The region is predominantly agricultural, with households involved in subsistence and small-scale commercial farming, and combining crop and livestock production. The principal cereals, grown largely for domestic consumption, are sorghum, millet, rice and maize. Root crops such as sweet potatoes and Colocasia (taro) or 'frafra' potatoes are also cultivated for household consumption and sale. Groundnuts, cowpeas and Bambara beans are legumes grown in almost equal proportions for home consumption and sale. Households are also involved in cash cropping of soya beans and tomatoes. Most households also raise sheep, goats and cattle as part of their portfolio of livelihood activities. 
The rural social structure is predominantly traditional, with communities organised around the leadership of 'Tindaanas' (i.e., earth priests, traditionally recognised as spiritual custodians of the land) and community elders in the exercise of customary laws and management practices in relation to access to agricultural land, grazing land, forests, and other communal resources [10].

Northeast Ghana is peopled by different tribes, including the Kasena peoples who are predominantly located in the Kasena-Nankana district, the Frafra of the Bolgatanga district and the Kusasi of the Bawku district (see Figure 1). Although these tribes have very similar cultural characteristics, they are classified as different on the basis of minor differences in their dialects [11].

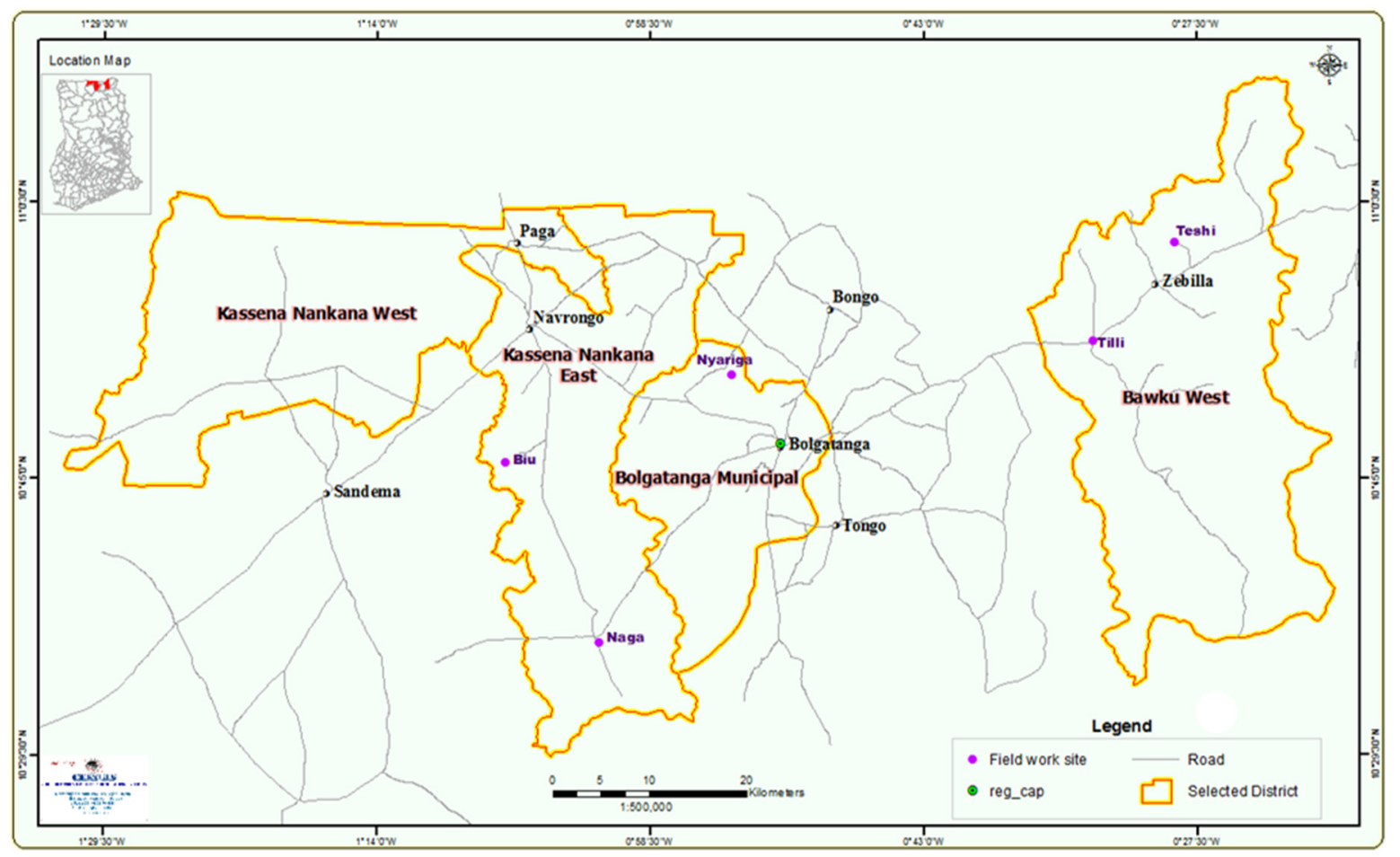

Figure 1. Map of Northeast Ghana Showing Three Tribal Districts.

\section{Materials and Methods}

\subsection{Conceptual Framework}

This study uses the political ecology framework to analyse the land-use/cover manifestations of the environmental, socio-economic and political processes shaping human-environment relations across different scales [12]. The adopted political ecology framework is underpinned by two key themes. The first is that understanding human-environment relations and its effects on land use and land cover outcomes requires integrated perspectives from both ecological studies and political economy so as to critically consider how the agency of different actors shape landscape changes over time $[13,14]$. Political economy considerations here encompass social structure (relationships between social groups and classes), institutional arrangements (government policies and regulations, customary rules and practises), and influence of market forces on the land use behaviours of various actors. The second theme emphasises that nature is understood differently by different actors (i.e., from local land users such as farmers to state land management bureaucracies such as environmental protection agencies), and the way it is understood is highly politicised. As Escobar [15] explains, conceptualisations about nature are formed, shared and applied in ways that are essentially political and socially mediated. This idea that nature is 'socially constructed' enables researchers to take a critical approach in deconstructing the narratives and interests that may define knowledge production 
processes about nature and the relationship between society and nature. Perhaps the most important point about the idea of social construction of nature is that the ways in which nature or environmental change is conceptualised has far reaching bearings on the way we interact with and organise our nature/space.

Critical examinations of historical processes and events in order to understand contemporary contexts is also central to the political ecology approach [16]. This historical reappraisal is very important because 'resource use histories' help explain contemporary and past landscapes $[17,18]$. It can allow us to understand the varied socio-economic and political processes that have shaped land use decisions and the manifestations of these land use decisions on land cover dynamics. Critical historical appraisal helps minimise or avoid tendencies for (mis)interpretation of long-term processes of land-use/cover change based on short-term snapshots.

The political ecology approach offers a more nuanced understanding of the interactions between social power (based on social categories such as class, ethnicity), conflicts over land resources, ecological conditions (such as climate variability) and their consequent land use change outcomes in the context of a broader political economy [14,19]. The examination of these issues is not only useful for understanding the broader political economic dimensions of agrarian change, but also for reinterpreting the desertification and agricultural development debates in the savannah agro-ecosystem region of West Africa in general [17] and northeast Ghana in particular.

\subsection{Data}

This study is mainly based on analyses of secondary data obtained from authoritative historical sources. The first anthropologically related written records on the political economy and ecology of northeast Ghana were written between the 1920s and 1930s by some officers in the British colonial administration, notably in the diaries and reports of Captain Robert S. Rattray, District Commissioner Charles Lynn and District Commissioner John K.G. Syme,. This historical secondary data is readily available from the archives of The Ghana Public Records and Archives Administration Department in Accra and Tamale, the George Padmore Library in Accra, and the Balme Library at the University of Ghana. Other information on evolution of the theoretical and empirical perspectives on the West African desertification debate was collected from academic sources such as books, journal articles, and other reports produced by the government and civic organisations concerned with desertification and land management. Reviews and analyses of this literature was complemented with visual observations of the landscape during my fieldwork. I travelled around the fieldwork communities with some local agricultural extension agents to assess specific locations such as forest groves, river valley areas and farmlands where significant changes in land use and land cover were reported to have occurred.

Lastly, based on these historical analyses and visual observations, I used CorelDraw software to illustrate the pattern of spatial organisation and how changes in agricultural land use during the pre-colonial and colonial periods were likely to have affected land cover changes.

\section{The People of Northeast Ghana: Contested Histories and Narratives of Land Use Change}

The history and origins of many ethnic groups in Africa is one that is very difficult to trace [20,21]. This difficulty stems largely from the lack of systematic documentary evidence. The ethnic groups in northeast Ghana region are no exception. Much of what is known about the history of these tribes is based on oral traditions (e.g., folklore, stories, songs) passed on from generation to generation. The recording of these histories are not singular or systematised, and it is possible to come across multiple versions of narratives for origins of tribes/ethnicities. But in reality however, there is always the expectation or need for a singular 'truth'. How this "truth" is established without the conventional written evidence is when history becomes a "contested" (but also conflicting) narrative ([22], p. 1). Such narratives are fluid and open to many variations in accounts of time (history) over space (geography) [22]. The literature is thus composed of numerous truths about the same ethnic groups and reflects writers' ideological assumptions about these histories. 
Syme [23] and Cleveland [24] wrote that the Kusasis migrated as small groups of clans from north and east of their present location, led by family and/or totemic clan heads. They were not centrally governed by a single leader. Fortes [11] explained further that the people initially settled as small families and clans in areas perceived to be conducive to farming, and they continued migrating across the landscape in response to push factors such as search for viable farmland, animosity between families/clans, and activities of slave raiders.

However, Rattray [25] noted that many of the 'original' inhabitants of the Upper East region were residing in or near the localities where they are found today. He further explained that small military bands from established kingdoms further north descended upon these indigenous communities, conquered and settled among them. They established themselves as a chiefly class, inter-married with the indigenous clans and adopted some of the indigenous cultural forms. Rattray further noted that before the onset of these 'foreign' warrior groups, the indigenous groups from related totemic clans were grouped and headed by 'Priestly-kings' or 'Tindaana' (Tindaanas, plural) whose power and authority depended on moral and spiritual punishment but not physical punishment and hegemony over a territory as characterised in the modern connotation of a king or ruler. It was these small groups of assimilated warrior bands, originally from established kingdoms further north, who changed the indigenous political system of leadership by the Tindaanas and their elders, and established a dual system where a chief and Tindaana co-existed simultaneously, especially in the major communities, with clearly defined roles for each party. The Tindaana acted as the spiritual guardian of the community, overseeing the spiritual well-being and land resources of the communities. The chief acted as the territorial ruler, seeing to the day-to-day administration of the chiefdom. These different historical accounts from Syme, Fortes, Cleveland and Rattray on the social structure and origins of the people that permanently settled in northeast Ghana illustrates the contested nature of the history. Rattray [25] attributes the cause of these contested multiple histories to the sources where the earliest writers of the history of Northern Ghana gathered their information from.

Notwithstanding these multiple histories, many aspects of the socio-cultural structure in the rural communities in northeast Ghana have experienced changes over time. Agricultural land-use and farming for instance have constantly changed as the people adapted to shifting environmental conditions, changing perceptions of their landscape, and changing social relations among themselves and with other peoples. Animosity and/or cooperation between neighbouring clans, activities of slave raiders, long and short-term climatic variations, excessive rainfall, acute droughts, shifting distribution of pests and diseases, development of indigenous tools and implements, expanding and/or decreasing family/clan sizes, among others, all affected the early history of the peoples. It affected their choice of settlements, selection and cultivation of seeds, general farming practices, perceptions, management, and organisation of their physical environment, social relations of livelihoods production, among others. Thus, the history of the peoples' relation with their environment has not been in a static environmental equilibrium sense, but has been fluid and constantly changing in anticipation and response to a wide range of complex social, economic, political, and ecological processes. As Cronon [26] observes, 'the instability of human relations with the environment can be used to explain both cultural and ecological transformations' ([26], p. 14) over time and through space.

\subsection{Role of the Tindaana}

This paper's account on the role of Tindaanas in the social and political organisation of the people of northeast Ghana during the pre-colonial era relies on the work of Cardinal [27], Rattray [25] and Tonah [28-30]. According to Cardinal [27], the communal and social fabric of the ethnic groups/tribes of northeast Ghana before the emergence of chieftaincy institutions (i.e., pre-seventeenth century) was traditionally organised around the moral and spiritual authority of Tindaanas in exercising the rules/taboos of earth gods and ancestral spirits. It is believed that the direct family ancestors of the present Tindaanas are the primordial residents of their respective communities. According to those beliefs, those primordial residents were the first to establish some sort of rapport with the nature 
spirits of the areas they settled permanently [25]. If they were able to build rapport with the nature spirits of a territory, then the primordial inhabitants could permanently settle there. But if this failed to materialize, then they died or had to migrate elsewhere. However, some controversy surrounds such primordial resident claims of the Tindaana clans. Other historical accounts claim that the first members of Tindaana clans who permanently settled in an area were not always the first to live in those areas. For instance, Cardinal [27] cited evidence from oral traditions and archaeological findings tracing human settlements by other early groups that were either nomadic (hunters and gatherers) or may have been killed by wild animals and/or disease.

According to Tonah [30], prior to the emergence of chieftaincy institutions around the seventeenth century and the genesis of colonial rule from 1874, Tindaanas were the sole religious and political heads of settlements in northeast Ghana. The Tindaanas regularly offered special sacrifices to the nature spirits inhabiting the land. The spirits in turn gave them a favourable environment for their livelihoods and protection as long they appease the nature spirits with sacrifices and desisted from activities that threaten their own wellbeing. Tonah further explains that new family or clan members wanting to settle in that area sought the permission of the Tindaana who, in turn, consulted the nature spirits to decide whether or not they should be allowed to settle there. All spiritual consultations referring to land were made with the spirit of the ancestral occupiers of that piece of land knowing that they were the first to own that land and that they might be angered if not appeased. The exclusive rights of the Tindaanas to perform the various religious rites associated with land access/usage and the belief that non-performance of those rites had serious communal and/or individual repercussions helped consolidate the position of Tindaanas as legitimate authority over land matters.

Tonah [30] also notes that the Tindaanas' role extended to maintaining 'harmony' between the people and their natural environment where they obtain their livelihoods. For instance, good fortune (e.g., bumper harvests, child bearing) or misfortune (e.g., low rainfall, childlessness, social conflicts) on the people's livelihoods and the community in general were linked to the people's adherence or otherwise to a code of conduct received from the nature spirits and made known to the people by the Tindaana. Boundaries about access and distribution of land resources, as well where not to use or not use for whatever purpose were set and enforced. According to Cardinal [27], the landscape around settlements was roughly divided into various traditional uses by the Tindaana, with the input of the community members. Some portions were reserved for grazing of livestock; others were reserved for hunting and collection of food, and later farming. This practice of traditional land-use planning continues to this day.

Each family and/or totemic clan usually had an animal or other living objects (such as certain plants/trees) or inanimate object (such as a cluster of rocks) that is considered sacred. According to legend, that animal or object possessed protective spirits that favoured their forefathers in the past. Thus, to kill such an animal or cut trees/plants from a certain area or tamper with certain rock arrangements or cut particular trees/plants amounts to disturbing the spirits that helped their forefathers and thereby incited some misfortune. When any of these rules or taboos were contravened, the Tindaana intervened by consulting and appeasing the nature spirits for restoration of ecological and/or social well-being. Thus, by establishing spiritual rapport with the nature gods, the institution of Tindaana established spiritual and social authority in a stateless area, as well as some sort of environmental stewardship.

\subsection{Land Inheritance Systems}

When land is allocated out by the Tindaana, it passes away from the direct control of the Tindaana to the clan, family or individual allocated to. The Tindaana sanctions usage, not ownership, of the land to the receiver [30]. Land cannot be sold, as it was believed selling land amounted to putting the nature spirits of the land into servitude [27]. Land was in abundance in relation to the population distributions at the time. Land allocated to families belonging to the various clans was divided among the married adult male members of the family. Tonah [30] explained that each adult male member used 
their land to cultivate grain crops such as millet (Pennisetum glaucum), groundnuts (Arachis hypogaea), beans (Phaseolus vulgaris) and sorghum (Sorghum bicolor) to feed their family. Upon old age or death of that adult male, his land assets were divided among his adult male sons, or daughters if he had no sons. Thus, the system of inheritance was purely patrilineal, with the arrangement that when a female member of the family marries into another family from a different clan, she can then access the land and other properties that their husbands have or inherited [30]. In issues of land access and use, women generally belong to the husband's family, but unmarried women can still access their father's land for use but not outright inheritance when the father dies [31]. Thus, although women had access to land through their fathers or families or husbands, their access to the land was not on a permanent basis as custom required them to leave and move to their husbands' land after marriage.

According to Cardinal [27], adult males were allowed to obtain their own plots outside of their family land area. They consulted the Tindaana for release of other unoccupied land to build their own compounds and farm. Labour shortages meant that immigrating clans and families were welcomed to settle there and take up land for their livelihood activities, as long as they came in peace and the traditional procedures were followed. Each family had a family council, usually consisting of elderly male members of the family, and chaired by a family head who is usually the most elderly male member of the family. The Tindaana only gave out land after consultations were made with the requesters' family council. If the requester was a 'stranger' in a certain family (i.e., not a member of a family by blood or marriage relations), the family council first formally admitted/accepted the person into the family in the presence of the Tindaana, who then completed the ceremony with necessary sacrifices. The approval of the family council was very significant because it ensured whoever was given land far away from their family and community was not considered an outcast. Thus, belongingness in a village or family formed the primary means for accessing land, and one's position in a village or family was critical in determining one's share of land resources.

The system worked such that the Tindaana never granted land that was left in fallow but already allocated to another family or person. It was possible for already allocated lands lying fallow to be reallocated to another family or person, but only with the permission of the first grantee of the land. These arrangements created an egalitarian system of tenure, embedded with many traditional systems of land and environmental management.

\subsection{Sacred Trees and Sacred Groves}

Traditional beliefs over allocation and uses of land also extended to the management of land cover. According to Cardinal [27], specific tree and crop species played very important roles in the belief systems of communities in the region, and there were certain restrictions and controls on their use, cutting, and distributions. For instance, except the felling of baobab, monkey guava or African Ebony tree (Diospyros mespiliformis), and the African locust bean tree, also locally called 'dawadawa' (Parkia biglobosa), people had the right to use all natural produce on parcels of land allocated to them by the Tindaana. The dawadawa trees on the landscape remained the property of the Tindaana, who harvested only the fruits and offered them to the nature gods. Whoever harvested the fruits of the dawadawa tree on their land, leaving nothing for the Tindaana to collect purportedly received the wrath of the nature gods. Each year, the people had to supply some sorghum (Sorghum bicolor), millet (Pennisetum glaucum), and other produce from their farms to the Tindaana as a form of rent payment for their land/farms. The total of these grain contributions were exchanged for sheep or a cow, which were then sacrificed to the earth gods. Sacrifices were offered in thickets of bush (or sacred groves, locally called Tingani among the Frafras) where it was believed the earth spirits resided. Such thickets were preserved for spiritual purposes, and no other human activity was permitted there (see Figure 2). The sizes of these scared groves varied, ranging from just a few hectares to some that are over hundred hectares in size. 


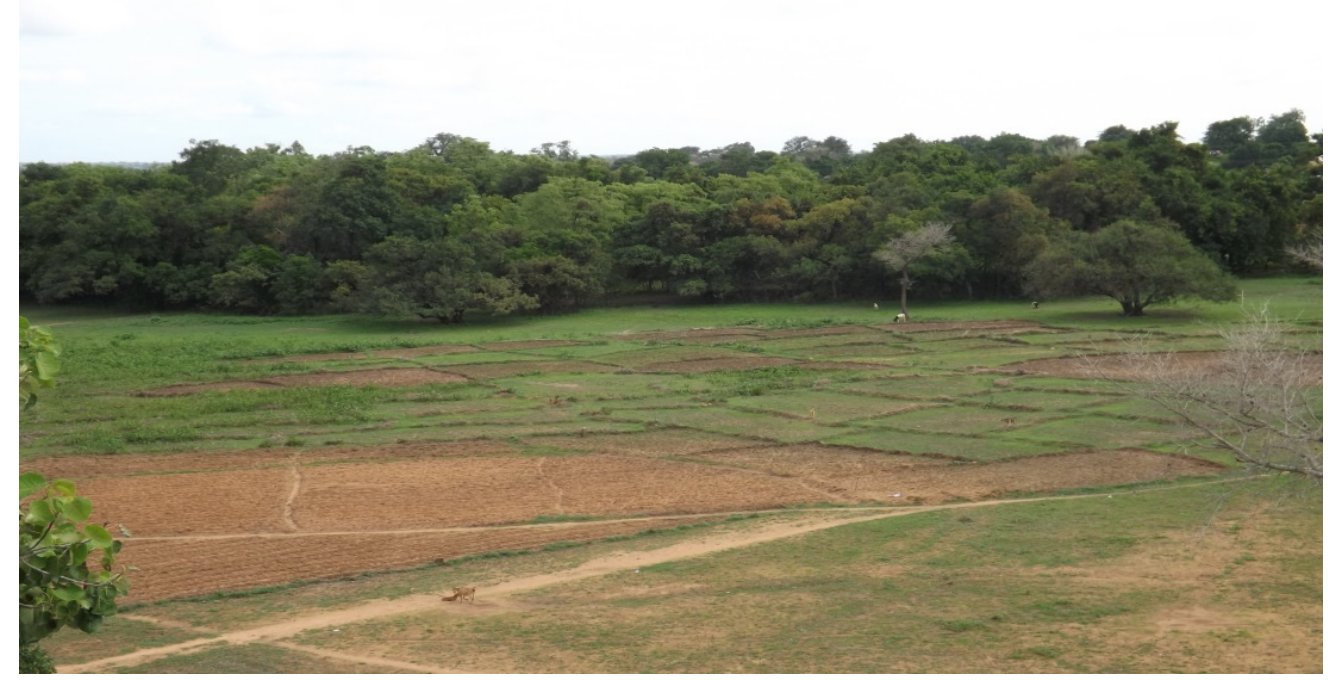

Figure 2. A Tingani Surrounded by a Vegetable Farmland in the Kasena Nankana District.

The issue of whether these patches of woody vegetation were remnants of an old forest that once covered much of the savannahs of northern Ghana has been highly debated. Early colonial ecological writers such as Auguste Aubreville and E.P Stebbing espoused the idea of forest groves as relics of an old larger forest ecosystem [32]. However, more evidence is being reported in recent studies suggesting that the anthropogenic factor in the creation and maintenance of many of those savannah woodlands has been under-estimated $[27,32,33]$. Anthropogenic influences over long periods of time, such as past human settlement and/or abandonment of an area, or social and cultural systems of human societies, have been advanced to have contributed to the formation and development of many of those forest groves. Cardinal [27] directly observed in the early 1900s that a clump of trees of quite recent growth in Sandema (in northeast Ghana) was later used as a Tingani upon revelation by spiritualists that it was a holy site for the earth gods. He described middens laden with evidence of recent tree growths on various sites:

'The middens in the bush are of more recent origin, as prove the trees which cover them, the pottery lying exposed and in many cases, the tailings from ancient iron-smelting. Even in the clusters of trees which today generally are the sacrificial places-clusters much thicker than one usually finds in the bush, as might lead one at first glance to believe they were remains of the original forest-one can still find middens, proving beyond doubt that the present forest grew over the land after it had been cultivated by man' ([27], p. 2).

More recently, Blench and Dengo [32] have done a review of archaeological materials in forest groves in northeast Ghana. They found that the forest groves usually consisted of;

'a clump of trees, generally containing more species than are found in the surrounding landscape, and often a mound or tumulus...The slopes away from the mound are frequently littered with tiny potsherds, indicating that this was originally a settlement site, either of this community or the one(s) that preceded it. The potsherds are recognised as making the soil particularly fertile, and there is a certain competition for fields immediately adjacent to the grove' ([32], p. 3).

Blench and Dengo [32] suggests that the forest groves were composed mainly of savannah tree species associated with human settlement and not too old. While there has not been any subsequent studies that have examined these claims, no critical evidence exists to suggest forest groves and other patchy woodlands on the landscape are relics of a hitherto largely forested landscape. 


\subsection{Land Use Patterns During Colonial Era}

From the preceding discussion, a few trends in land use and land cover changes in the pre-colonial societies of the study areas can be discerned. The first relates to initial clearing, by early settlers, of grass and shrub dominated portions of the landscape for establishment of permanent settlements and farms. The likelihood for clearance of portions of the landscape for settlement and farming depended greatly on cordial relations with earth and ancestral spirits of a place, accessibility of that area, the protection it offered from rival attacks, and perceptions about suitability of a place for certain agricultural practices. This was probably followed by agricultural/farm expansions and resettlements as population increased in some areas as a result of immigration, emigration, and natural births. Land cover may be altered in relatively inaccessible and 'unfriendly' areas such as the river valley areas initially by groups of migratory locals. These places may be abandoned and reoccupied as times goes on, as seasonal incidences and activities of pests such as the trypanosomiasis-causing tsetsefly, for example, will discourage permanent human settlement.

Figure 3 illustrates the pattern of spatial organisation and how mutations in the agricultural frontiers and land holdings during the pre-colonial were likely to have affected land-use/cover changes in the study areas.

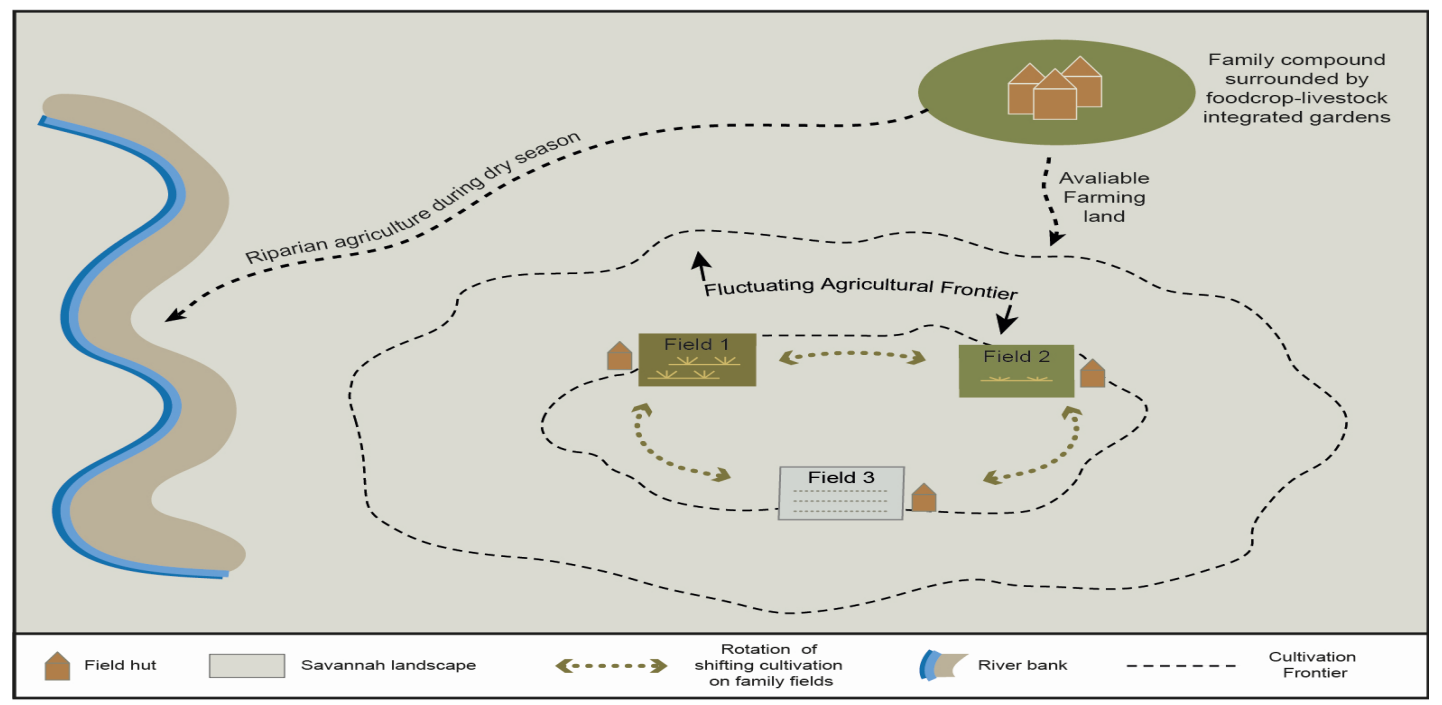

Figure 3. Patterns of Spatial Organisation and Changing Land Use during Pre-Colonial Period.

From Figure 3, agricultural and land use organisation during the pre-colonial era followed a pattern of concentric rings around circular compounds. Two main types of land holdings for individual families and households can be identified - the compound land/farm and the family land/farm. Compound houses were built on the compound land, and concentric compound farms immediately surround the compound houses. Based on labour availability, inputs supply (such as manure), and other natural conditions such as rainfall distribution, a few sectors of concentric compound farmlands were cultivated for a few years while the other sectors were fallowed. Alternatively, the entire circumference of one concentric layer of compound farm was put into production while other layers lie in fallow. Local staple food crops such as finger millet, sorghum, and beans were cultivated on the compound farms.

Some distance away from the compound land/farm was the family land/farm. On the family land, cultivation was organised along strips, with the strips being opened up or shrinking in response to labour availability, input supply, and natural factors as the years go by. A few homesteads were built on the edges of the cultivated lands where farmers may be able to stay and/or store produce, thus lessening the burden of having to travel or carry heavy stuff for long distances each day between their compound and the family farm. Cultivated lands may be left to fallow while unused land already lying in fallow may be put into agricultural production. Homesteads followed the same pattern and were 
relocated on the edges of the new cultivation land. Intercropping was widely practiced on the family, cultivating crops such as groundnuts, pearl millet (late millet), sorghum, and cowpeas. Some dry season farming may also be practiced along riparian areas such as banks and floodplains of streams and rivers. Although staple food crops and vegetables may be cultivated, riparian areas were largely devoted to crops that do well in swampy conditions, such as rice.

\section{Colonial Rule in the Northern Territories}

The British started making incursions into the northern territories of present-day Ghana in 1874 after overcoming the Ashantis, whose empire at its zenith stretched from the middle zone of Ghana to the Atlantic coast and the transition belt between the moist semi-deciduous forest in the south and the northern savannah areas. But it was not until 1896/7 that Britain annexed the whole northern regions of present-day Ghana after warding off the advances of the French and Germans as well as the campaigns of African slave raiders such as Babatu and Samori Toure [20,34]. Formal treaties were signed between the British, the French and the Germans to demarcate the boundaries of the Northern Territories, and in 1901 the area was officially made a Protectorate of the British. The British subsequently divided the entire northern Ghana (officially called Northern Territories at the time) into centralised state societies and non-centralised societies [35]. The centralised stated societies were found to the south of the northeastern and northwestern parts of Ghana. Such societies included kingdoms such as the Mamprusi, Dagomba, Mossi, and Gonja, that had paramount chiefs and divisional chiefs who were recognised by the British. Although Indirect Rule had not been officially introduced at this period, the British ruled through the chiefs and local 'big men'. These chiefs were required to administer justice, collect taxes, and mobilise labour. Before the early 1930s, the British controlled these areas through the chiefs. This was different from the later policy of Indirect Rule under which chiefs were given the authority to rule, in accordance with the British colonial government's principles and directives [36].

Many of the societies in the north-eastern region were small and not centralised like their immediate southern counterparts. The Tindaanas' authority in these societies rested not on physical control over people and territory, but religious powers to intermediate between the people and their ancestors and earth gods. Although some communities in the northeast developed chieftaincies after the arrival of Mamprusi warriors in those places, the British found it relatively difficult ruling in the many parts without chiefs. They considered the Tindaanas as 'traditional' and 'backward', not suitable for the colonial aims of 'modernising' the societies and integrating them into the national and international economy [30]. Resistance to British occupation was intense in these areas, so that the British had to militarily suppress these peoples and install chiefs among them through whom to rule [37]. Figure 4 is a copy of an original document written by a District Commissioner to inform the Chief Commissioner about the challenges of bringing the local people under British colonial authority. Captain Read, the District Commissioner wrote:

"these....are an exceedingly turbulent lot and they will not recognise any authority. If any man is wanted for any offence in this part he invariably absconds and though I have warned the chiefs (where there are any) that they will be held responsible for the behaviour of their people, they have so little authority that they are useless to the Administration."

Such perceptions of colonial political officers about ineffectiveness of some chiefs and difficulties in ruling the people necessitated the installation of 'stronger' chiefs backed by the colonial administration. Many local 'big men' were considered for the chieftaincy roles. This move by the British also partly created a dual system of traditional authority that has persisted to this day in northeast Ghanaa system where secular chiefs exist side by side with religious Tindaanas. These colonial government appointed chiefs usually had no primordial settlement claims to where they were installed as chiefs. According to Laube ([37], p. 55), many of them manipulated the system to some extent for their personal benefit. Some chiefs sold occupied lands to multiple parties. However, such chiefs and others were removed and replaced for such acts and if they fell out of favour with the colonial government. 


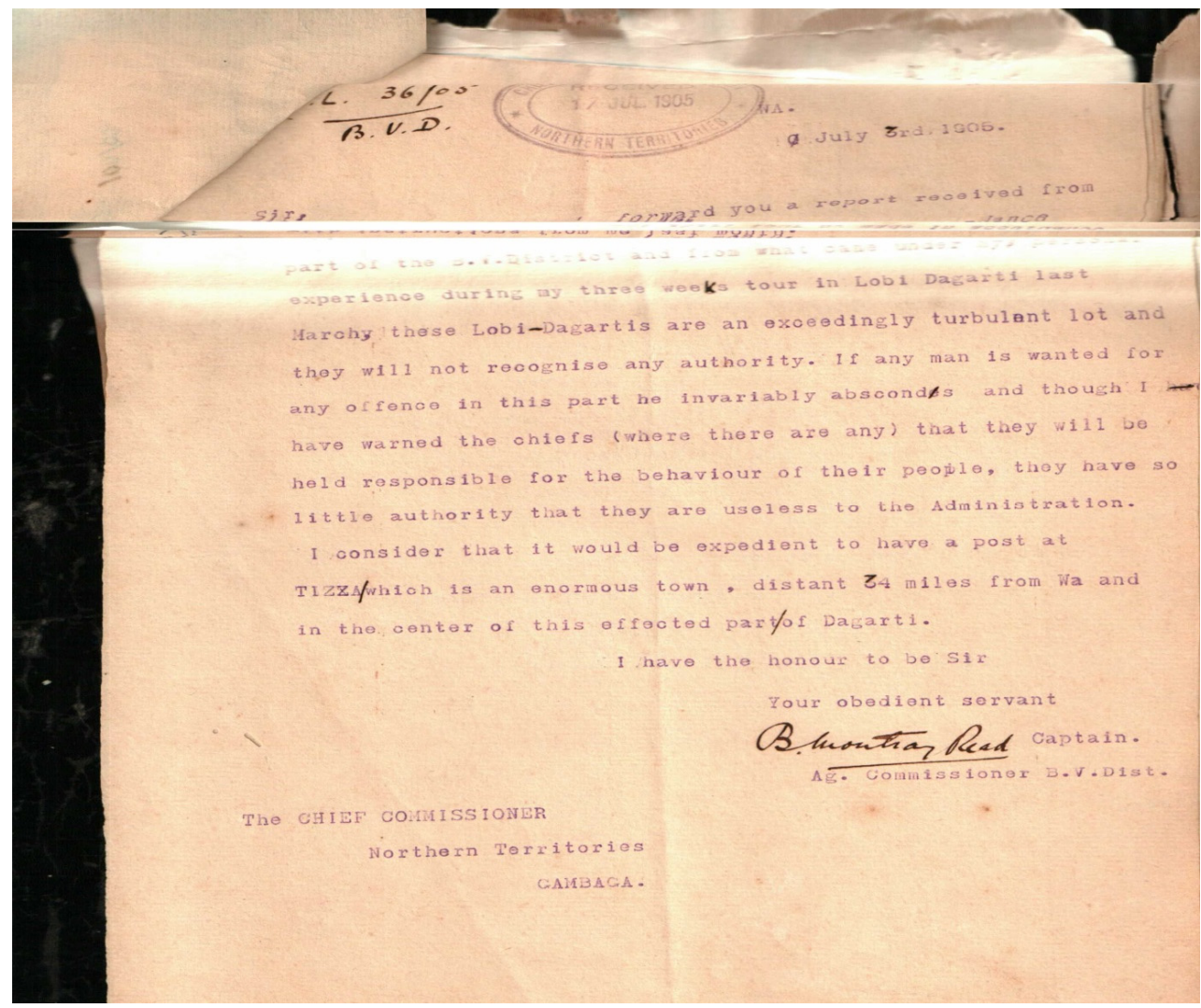

Figure 4. Letter from Colonial Military Officer, Captain Read, Addressing Challenges of Bringing Locals under Authority. Written in 1906. Source: [38].

\subsection{Colonial Economy in the Northeast Part of the Northern Territories}

Apart from resistance from the local people and the "misconduct" of some installed chiefs in the northeast, the colonial government faced other challenges. Financial resources were needed to meet costs of running the Protectorate. Surveys were conducted to study the resource endowments and potential of the region. The caravan trade in local goods between the societies in the West African interior and peoples of the Ashanti kingdom passed through these areas, and it provided the first option for revenue generation to the British through tax impositions [39]. Other avenues for revenue generation, such as cotton planting and cattle rearing, were encouraged [35]. A decline in caravan trade volumes because of heavy taxes, activities of slave raiders, and limited success of cotton and cattle production forced the colonial government to abolish the caravan tax scheme around 1908 in order to attract more trade and goods supply [40]. Attention again diverted to cash cropping and cattle rearing to supply the markets in Ashanti and other parts of the Colony and beyond, but these measures were also not very profitable. Lentz [41] and Nabila [42] have documented a number of factors that accounted for this. Choice of cash crops and their suitability to rainfall and ecological conditions in the northern savannah was one. Others include poor transportation networks to rapidly link the northern territories to the markets in relatively urbanised centres down south. A shortage of labour in many parts of the northern territories was another. At this time, the booming cocoa industry in the Ashanti Colony was partly a result of hard working labour shipped from the northern territories. The lucrative nature of the cocoa business prompted the British to bring labour from the northern territories and from the francophone Sahel to work as forced labourers on government farms, mines, and infrastructure projects. After abolishment of forced labour in 1925, voluntary labour migration soon took off, as more northern peoples migrated to the south for waged work [37]. 
Epidemics such as cerebral meningitis and influenza also contributed in decreasing population and labour supply in the Northern Territories at the time. Howell [34] reported that about 10,000 died from a cerebral meningitis outbreak in the Northern Territories in 1907, and at least 28,000 died as a result of influenza outbreaks between 1928 and 1929. In the areas covering the present-day Kasena-Nankana and Bolgatanga districts alone, 15,000 died [34]. The continual loss of population through forced and voluntary labour migrations as well as epidemics deprived the Northern Territories of labour and human resources needed for agriculture.

\subsection{Land Tenure Systems Under British Colonial Rule}

The activities of the colonial government (and their appointed chiefs) had profound effects on customary land tenure arrangements in place. It fundamentally undermined the allocation and use systems that functioned under the authority of the Tindaanas. Land assumed increased economic value as the British colonial government moved to put the administration of land under the control of 'Native Tribunals' that were to issue temporary land occupancy rights and to make any land available whenever the government needed it for 'public good' [43]. These measures were instituted from 1902 when the British introduced the Native Administration Ordinance (Cap. 111) [37]. Under this ordinance, monetary rents were extracted for temporary occupancy rights, as opposed to pre-colonial customary land tenure rights. The sidelining of the authority of the Tindaana and the increasing economic value of land culminated in a number of (sometimes bloody) civil land boundary disputes between natives, which were handled by the chiefs, and later by the colonial courts. It is on record that an outbreak of riots in the Bongo area of northeast Ghana in 1916 was as a result of such land disputes [35]. I obtained a colonial government report on those disputes from the Public Records and Archives Administration Department in Tamale. It is shown in Figure 5.

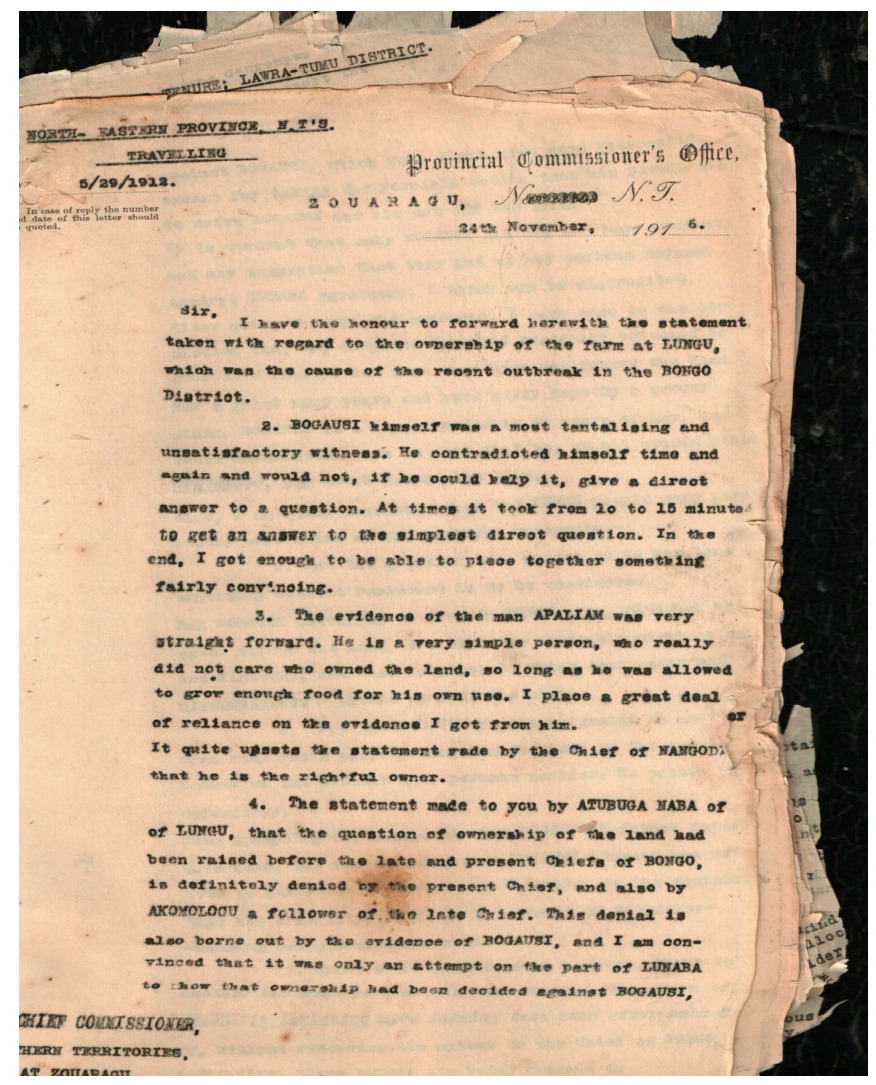

(a)

Figure 5. Cont. 


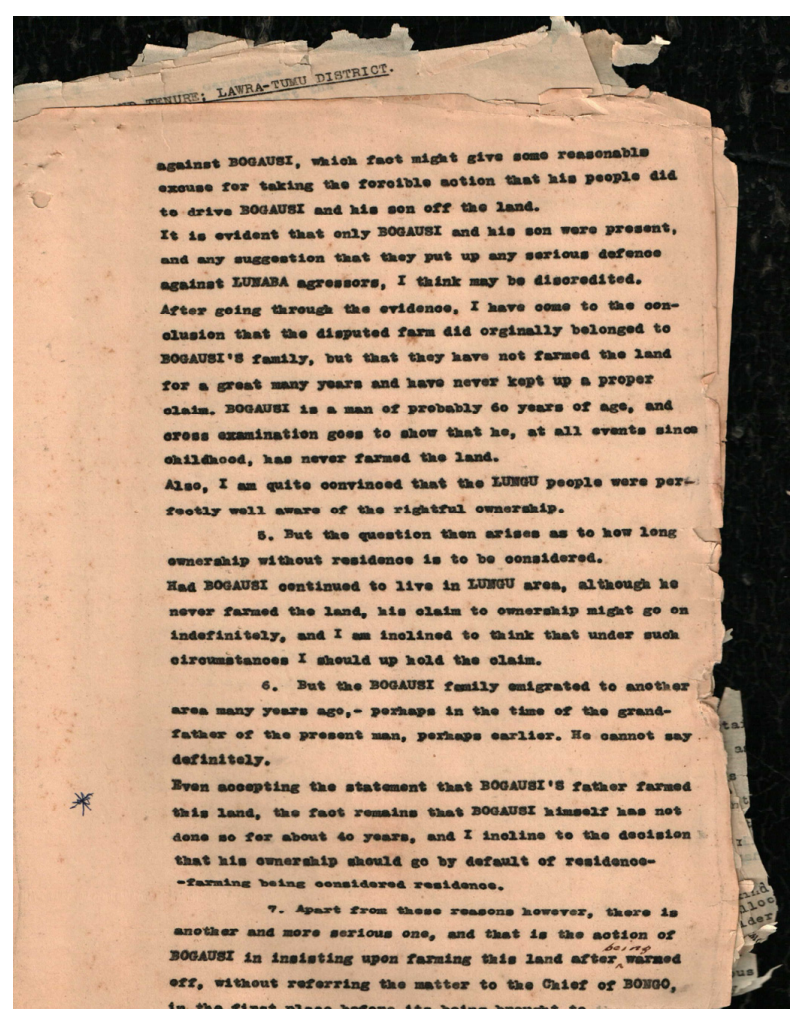

(b)

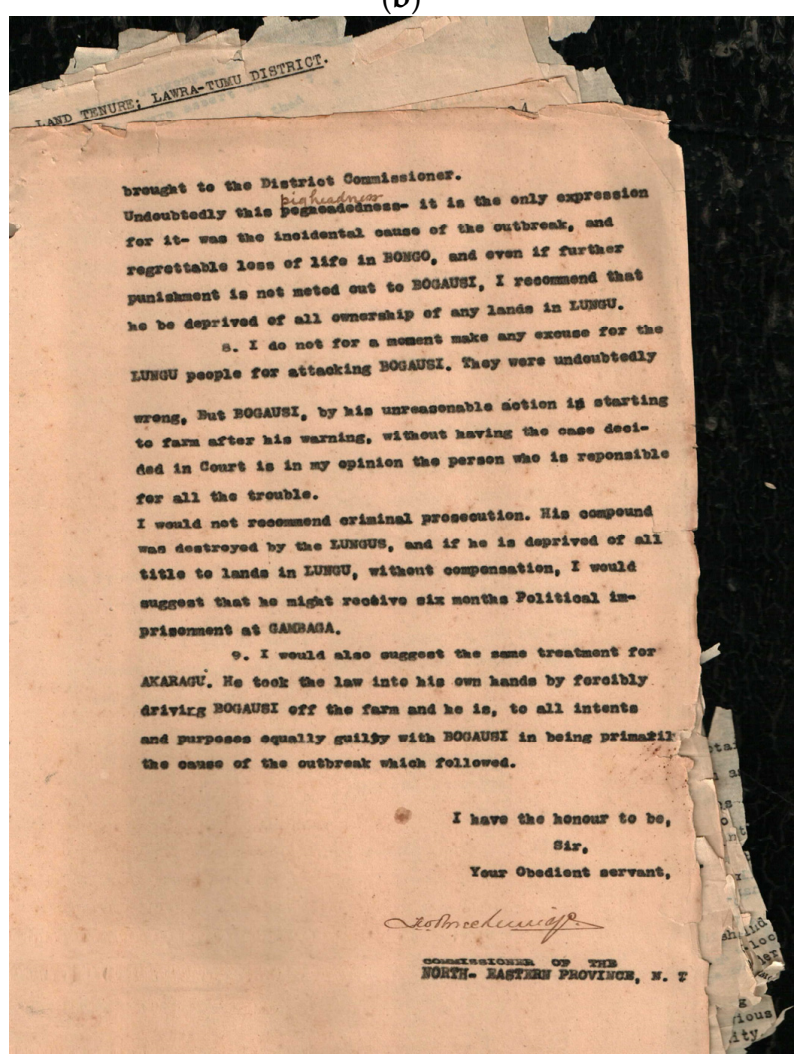

(c)

Figure 5. Colonial Government Report on a Land Dispute in Northeast Ghana, 1916. Note the multiple claims of ownership to the same piece of land, reflecting a change in the land ownership system from communal to private property rights: (a) Report by Commissioner of Northeastern Province on a Land Dispute Case; (b) Continuation of Report by Commissioner of Northeastern Province on a Land Dispute Case; (c) Continuation of Report by Commissioner of Northeastern Province on a Land Dispute Case. Source: [38]. 
From the report, there was a land dispute between two persons-Bogausi and the chief of Lungu, a community in the Bongo area. Bogausi claimed ownership to a block of land in Lungu, although he lived elsewhere outside Lungu. When Bogausi and his son started farming on the land, the Lungu chief and his followers challenged Bogausi's use of the land and warned him not to continue farming on it. Their claim was that he was neither a resident of Lungu nor the rightful owner of that land. Bogausi however ignored those warnings and went ahead to farm on that land, claiming that the land belonged to his grandfather, who lived in Lungu before emigrating. Physical confrontations then ensued between the supporters of Bogausi and the chief of Lungu, leading to loss of several lives. In addition to Bogausi and the Lungu chief, the chief of Nangodi also claimed to be the rightful owner of that land. This story of multiple ownership claims reflects the change in land ownership conditions from communal to private property rights.

The colonial government identified the accelerated rates of land encroachment/disputes as a problem caused by traditional systems of land access [44]. They saw the 'communal system of land holding' as 'an obstacle to progress' ([45], p. 61). But in reality, the increasingly changing value of land in economic terms meant that certain people now with power in society, such as the appointed chiefs, 'big men' and other locals connected to rich merchants, claimed private holding rights to land so they could sell.

In 1927, a Land and Native Rights Ordinance was passed which vested all lands, whether occupied or unoccupied, in the direct control of the Governor of the Gold Coast on behalf of the natives [37]. Lands already under occupation by natives had to be registered, and land could now only be leased through occupancy rights certificates that people had to apply for from the colonial government [46]. The ordinance spelt out conditions under which the right to occupancy of land can be revoked. It is interesting to note that one of the conditions under which land occupancy rights could be revoked can be linked directly to the story of the Lungu land disputes discussed earlier. The colonial officer who wrote the report noted that while Boguasi's grandfather may have used the land in the past, for over 40 years Bogausi was neither a resident of Lungu nor lived/worked on the land in Lungu to be considered the rightful owner of that land. This led the writer to question 'how long ownership without residence is to be considered'. From Section 13 sub-section E in Figure 6, the Land and Native Rights Ordinance stated that:

'It shall not be lawful for the Governor to revoke a right of occupancy granted as aforesaid save for good cause. 'Good cause' shall include....abandonment or non-use of the land for a period of two years, provided that when land is allowed to lie fallow for purposes of recuperation of the soil it shall not be held to have been abandoned' (Land and Native Rights Ordinance, 1927).

The colonial government also asserted the power to nationalise parcels of land anywhere and at any time that they deemed necessary [47], as shown in Figure 6. These attempts by the British colonial government to absolutely control land matters in the Northern Territories marked the genesis of narratives about the need to transform natural resource access/use regimes [37] and to address problems of low agricultural productivity and land degradation. 


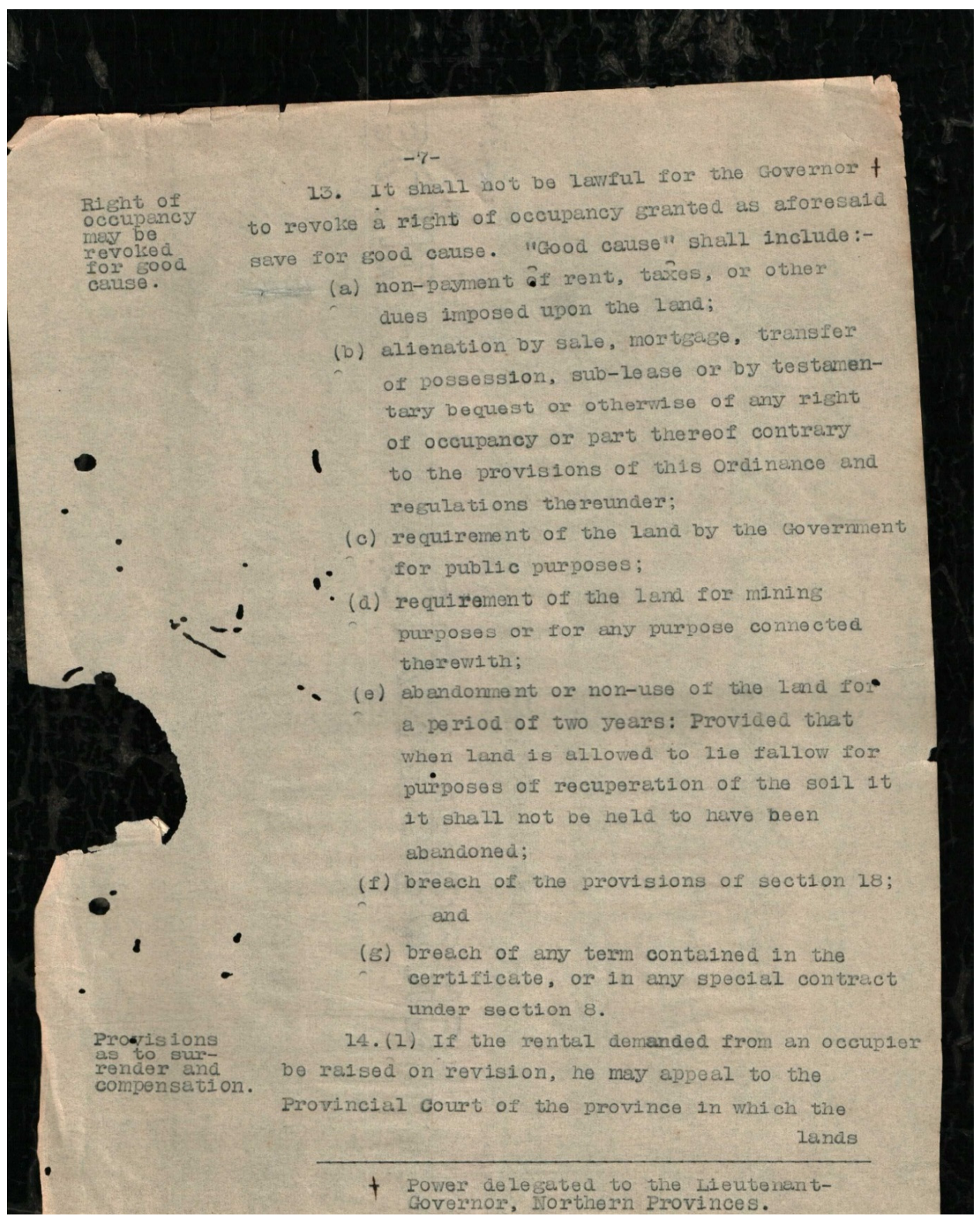

Figure 6. A Section of the Land and Native Rights Ordinance on the Colonial Government's Right to Revoke a Land Occupier's Right of Occupancy. Source: [38].

\subsection{Colonial Narratives of Native Land Degradation}

The colonial government's concerns with land degradation by the natives emanated from a perceived threat of the effects of human induced bushfires on vegetation conditions, hydrological regimes and fertility of the land. This perceived threat informed the colonial government's push for greater control of land and forestry resources so as to protect them from 'profligate' African land use practises [37]. According to Wardell [21], the push for greater control of land was also for two main political reasons. The first as a means of exercising absolute political control in the process of state formation, and second as part of efforts to reserve forestry resources, improve agriculture and appropriate suitable land for production of fundamental agricultural products to support the northern economy. This latter concern stressed the need to limit the expansion of subsistence farming into what the colonial conservation officers called 'marginal or fragile' areas and the redistribution of population in these areas so that the local ecology's carrying capacity was not over-stretched $[39,48]$. It was propagated that a lean but efficient farming sector would boost agricultural productivity (and 
industrial development) while limiting the number of 'wasteful' shifting cultivation practicing peasants who rely on inefficient and unsustainable practices for mere subsistence. Another component of the plan was to secure freehold land and make it available for investors who would produce poles, lumber, and cash crops [21]. These were parts of state-led land reform efforts to put the northern territories into the global capitalist economy as early as the beginning of the twentieth century [49]. It was with these concerns that formal land planning and control efforts in northeast Ghana can be traced. Between early 1900s and the 1940s, the colonial government laid out this agenda concurrently in two main forms-the 'agricultural productionist' form and the 'conservationist' form.

\subsubsection{The Agricultural 'Productionist' Form}

Under the agricultural productionist form, the colonial agricultural and conservation officers introduced programmes and projects to boost agricultural production and environmental conservation at the same time. These included the formal promotion of mixed farming for increased food crop production, as well as cattle production and large scale livestock immunization drives, cotton production, shea butter production, groundnut production, among others [34]. These measures were initiated at a time when booming production of cash/industrial crops (such as cocoa) in the southern part of Ghana had affected food crop production, and the government wanted to intensify food crop production in the north to make up for the growth in expensive imports of food and other agricultural produce [37]. Figure 7 is an extract of a colonial government report on strategies for introducing capitalist relations of production in agriculture through the promotion of commerce, encouraging agricultural production beyond subsistence levels, and establishing railway networks for cheap export of crops from the Northern Territories. Writing in 1927, the Principal Superintendent of Agriculture and Forestry noted that:

'In the Northern Territories speaking generally, the lack of interest shown by the population in growing crops for money seems to be because once having money there is nothing to spend it on. With the advent of a railway, the inevitable result would be the establishment of stores, and, with the right kind of goods which appeal to the native, it would act as an incentive to him to grow crops, as, by this means alone, is he able to obtain money beyond what is necessary for him to live... With the advent of cheap transport there seems no doubt that an export of products from the Northern Territories could be established.'

These strategies were implemented but available records indicate that their successes were limited. Der [50] reported that high fluctuations in rainfall conditions, relatively poor soils, and the colonial government's disregard for traditional political-economic relations of production and social life prevented the large-scale implementation of these strategies. Der [50] also noted that the peripheral status of the Northern Territories, in terms the availability of readily exploitable natural resources and export revenue generation capacity, did not encourage the government to commit much developmental attention to the region. Figure 8 illustrates the views of the colonial government on committing resources to the development of the Northern Territories. The Governor (head of the colonial government) and other high ranking colonial officers such as General Gray shared the opinion that:

'so long as there is no established industry or product being carried on in, or exported from the Northern Territories, the country cannot be developed' (General Gray, 1929).

From Figure 8, there also seemed to be disagreements among colonial officials about the development of some agricultural sectors such as sheep rearing in the Northern Territories. While the Principal Veterinary Officer noted that 'no wool breed of sheep would thrive in the Northern Territories', the Governor responded to that view by stating that he saw a healthy woolly breed of sheep in the Northern Territories and that he is 'desirous of proceeding with any well considered experiment' on the viability of commercial sheep rearing in the Northern Territories. Given these uncertainties about potential of the Northern territories and the failure of past attempts at promoting cash crops and 
commerce, the agricultural resources of the area could not be developed faster and/or effectively to make it profitable and justify development investments there. The area was subsequently considered for supplying labour to work in the more profitable commercial farms and mines further down in southern Ghana.

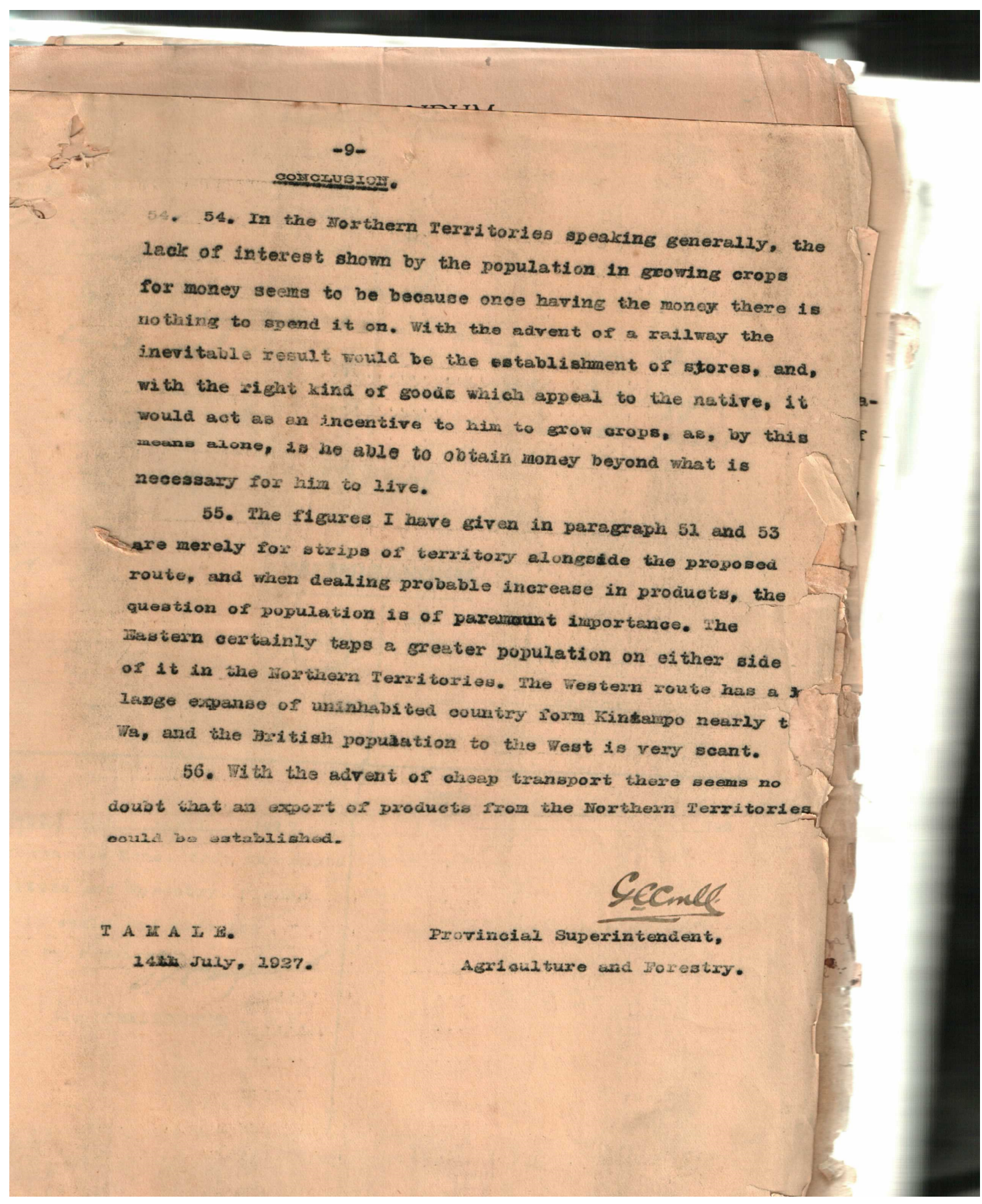

Figure 7. Extract of Colonial Government Report Detailing Plan to Introduce Capitalist Relations of Agrarian Production into Rural Life. Source: [38]. 


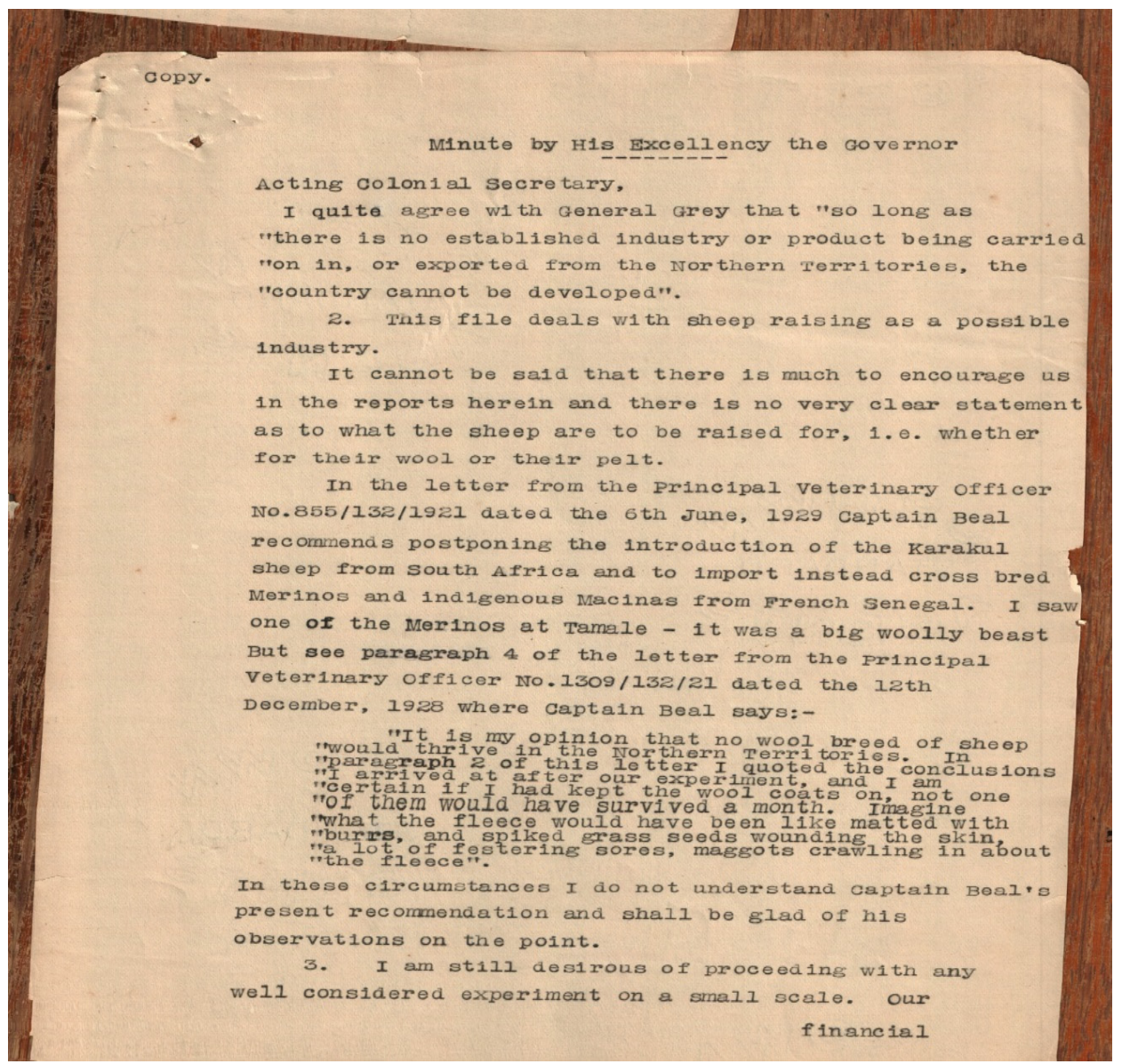

Figure 8. Copy of Minutes of a Meeting between the then Governor and Some Agricultural Officers. Source: [38].

The general perception of the British colonial administrators was that the traditional organisation of subsistence agricultural production was unsustainable and counter-productive, and was the primary cause of numerous cases of food shortages in the Northern territories and other parts of Ghana $[39,50]$. Not much attention was given to the effects of seasonal rainfall variations on food availability at certain critical times of year. The main rainy season from May to October was shorter than the long dry season which lasts from October to April, meaning that there were possible 'hunger season' periods towards the end of the long dry season when subsistent farming households consumed all the crops produced in the previous farming season [39]. The colonial government initially responded to this 'hunger season' situation by sending in famine relief items to the northeast of the Northern Territories. But this move proved unsuccessful as the poorly developed transportation network in the northeast made it very difficult to transport food there [51]. More importantly was a survey to reassess the famine situation and the subsequent realisation that it was not as bad and acute as feared [39]. The government commissioned Charles Lynn in the 1930s, an agronomist who had been brought in from his previous station in northern Nigeria where he was in charge of implementing improved farming programmes. He was tasked to closely study agriculture and food shortages in the Northern Territories, especially northeast Ghana. Lynn's assessment was that hunger was very severe in the densely populated areas in the northeast, and that appropriate soil and water conservation methods should be applied to remedy the problem of 'careless and wasteful' farming methods ruining the soil and the agriculture industry in the Northern Territories ([52], p. 82). 
Long and short-term proposals for management of soils and the agriculture industry in the Northern Territories were made, mainly based on Charles Lynn's recommendations. The short-term plan included intensifying production through intensive application of manure derived from the increased range of livestock that farmers would be trained to rear [52]. The long-term strategies included increasing farm holdings from an average of 2-4 acres per farming household to about 8-12 or more acres so that intensive agriculture could be practiced on larger land holdings [53]. This programme also proposed the creation of a lean efficient farming sector, with forced migrations of communities into perceived food-sufficient areas and redistribution of land to a few farmers who were deemed progressive to achieve the government's aim. Grischow \& Weiss [39] report that about 80,000 "surplus" people from the Upper East region were forcefully evacuated and resettled to work in state farms established on uninhabited land further south of the Upper East region. The fallow lands left resettlement were used to establish forest reserves and state farms for production of cash crops such as groundnuts and silk cotton [53,54]. According to Grischow and Weiss [39], many of the 80,000 natives who were resettled from 'over-populated' areas in northeast Ghana were moved to newly created villages around large scale state plantations and communal farms established on unoccupied lands around Damongo, about $120 \mathrm{~km}$ further south of northeast Ghana. However, some of the resettled peasants and individuals left their new villages and migrated to live with relatives and/or friends in communities in the northeast hinterland or other remote areas where colonial government influence and presence was less pronounced/visible. Here, they sought land from appropriate sources, established their compound settlements, and cultivated a piece of land for their livelihoods. Other resettled peasants migrated down south to seek manual labour employment in lucrative mines, state plantations, and government departments.

Out-migration of peasants from the state commercial farming scheme areas was so rampant that fewer than 4000 settlers remained in the Damongo scheme by the mid-1950s, and that particular scheme was liquidated in 1956 [39]. Grischow and Weiss [39] explained a number of factors that accounted for the out-migration. The state farm model in place was to organise production as collective groups on communal lands that were large enough to benefit from large scale mechanized farming. Collective production groups were to be led by appointed chiefs and local leaders who received inputs and negotiated for other facilities from government for onward distributed to members. The leaders also managed harvesting, storage and distribution of farm produce. However, it appeared that the successful negotiation of access to the facilities and inputs by ordinary local people was the exception, not the norm, as some government-appointed local leaders and chiefs abused the system for their own gains. Thus, the level of success of these state commercial farm schemes, especially in meeting colonial agricultural development targets, was very limited. Other factors also contributed to the limited success of the colonial agricultural initiatives. Communal farming was not very popular in pre-colonial northeast Ghana, where settlements were very sparsely populated and distributed, and agricultural production was organised purely around individual household labour resources [30]. Incidence of locusts and other pests and diseases also affected productivity [39]. While Lynn was conducting his survey and making his proposals in the period between 1932 and 1937, the region experienced low rainfall (as reported in Dietz et al. ([55], p. 153)). This combined with activities of locusts and other pest and some localised incidences of soil erosion further negatively affected agriculture [39]. These turn of events contributed to strengthen the meta-narrative and conviction of colonial officers political such as Lynn that activities of peasants are causing or affecting land degradation, thereby impacting on agriculture productivity and food security.

\subsubsection{The Conservationist Form}

Extensive surveys were organised by the colonial government to study the feasibility of establishing forest reserves in strategic areas in the northeast. These forest reserves would protect headwaters of important rivers and streams while supplying forestry products such as teak, poles, and other lumber. These moves ushered in a conservationist form of land planning and control already 
present in other British colonies in West Africa, notably in Sierra Leone [56]. It saw the creation and gazetting of a number of forest reserves and the subsequent resettlement of large populations to other areas outside the reserve zones and not deemed over-populated [53,54].

Most of Lynn's recommendations were approved and codified as part of the land planning policies borne out of the 1947 North Mamprusi Forestry Conference (see [57]). This conference produced plans that divided the entire northeast into forest reserve areas and arable areas [39]. According to Grischow \& Weiss [39], in the arable areas, large plantation-style state farms were established on unoccupied lands in areas that were not considered 'marginal' (usually outside the Upper East region), and peasants from the areas in the Upper East region that were considered marginal and over-populated were resettled on these state plantations where they worked on the state farms for small wages. Crops such as tobacco, groundnuts, tomatoes, silk cotton and other cash/export crops were mainly cultivated on the large scale state farms.

Wardell [1] reports that established forest reserves areas in the Northern Territories rose from an area of only 160 square kilometers in 1939 to an area of 4193 square kilometers by the end of the colonial period in 1957, constituting 60 forest reserves. Of this figure, more than half were gazetted in the northeast region alone, though the northeast region constitutes less than 10 percent of the total area of the Northern Territories.

\subsection{Land Use Patterns during Colonial Era}

A number of inferences about changes in the organisation of space and land-use/cover patterns during the colonial era can be drawn from the historical narrative discussed. First, the most striking development was the division of the entire Northern Territories into centralised kingdoms and non-centralised societies, with the study areas in the Upper East region falling within the non-centralised societies. The appointment of 'big men' as chiefs in these non-centralised societies had far reaching effects on pre-colonial pre-existing customary land tenure arrangements and organisation of space. Appointed chiefs and local 'big men' who could manipulate the system to their undue benefit bypassed the authority of the Tindaanas in land access and usage issues. Land could now be sold or leased for monetary rent, thus increasing the economic value of land such that there was scramble for private property rights in land often to the disadvantage of powerless peasants. The practice of approaching the Tindaanas for land for settlement and cultivation purposes seemed to fade as the British deliberately sought to dismantle the egalitarian system of land tenure around the authority of the Tindaanas. Dismantling the pre-existing egalitarian system of land tenure was embarked on by the British so that they could control land totally, strengthen their political authority, and roll out natural resource extraction and other commercial farming ventures to pay for the costs of running/administering the Protectorate. Changes in organisation of space and land-use/cover patterns during the colonial era are diagrammatically represented in Figure 9.

Cultivation of cash crops such as cotton, tobacco, rice, and vegetables expanded considerably, meaning that more unoccupied lands in the bush and around communities that were formerly devoted to staple food crop cultivation were now taken over by pseudo-capitalist farmers who cultivated cash crops such as cotton, tobacco, rice, and vegetables. Increasing economic value of land and weakening authority of the Tindaana also meant that land allocated to native households for farming were reduced in size and in spatial extent, in comparison to the expansion of state commercial farms and increasing acquisition of land. Decreases in population through forced labour migration, later voluntary migration, and mortality through pests, diseases, and epidemics also contributed in reducing the frontiers or spatial extent of native farmlands at this period.

From the 1940s onwards, the colonial government's plan to transform the fortunes of agriculture in the northeast and to pursue land use planning for the benefit of the colonial state, had considerable effects on the organisation of space and mutations in land-use/cover patterns. First, mixed farming initiatives promoted by the government actively encouraged the expansion of individual land holdings (from 2-4 acres to about 8-12 or more acres) to small numbers of 'progressive commercial farmers' 
(i.e., capitalist farmers) but forcibly resettled a lot of 'wasteful' peasants to other newly created land planning areas (usually outside the Upper East region) so that a lean but efficient capitalist farming class could be created. It was on the plan that this lean but efficient capitalist farming class would intensify production of larger land holdings per household, but these measures largely failed. Many of the resettled peasants and individuals left their new villages and migrated to other areas in the hinterlands and other surrounding remote areas in the Northern Territories where colonial government influence and presence was less pronounced. In essence, these migrations effectively expanded the frontiers of agricultural land use as the new migrant settlers sought land from appropriate sources, established their compound settlements, and cultivated parcels of land around their compounds and in bushes for their livelihoods.

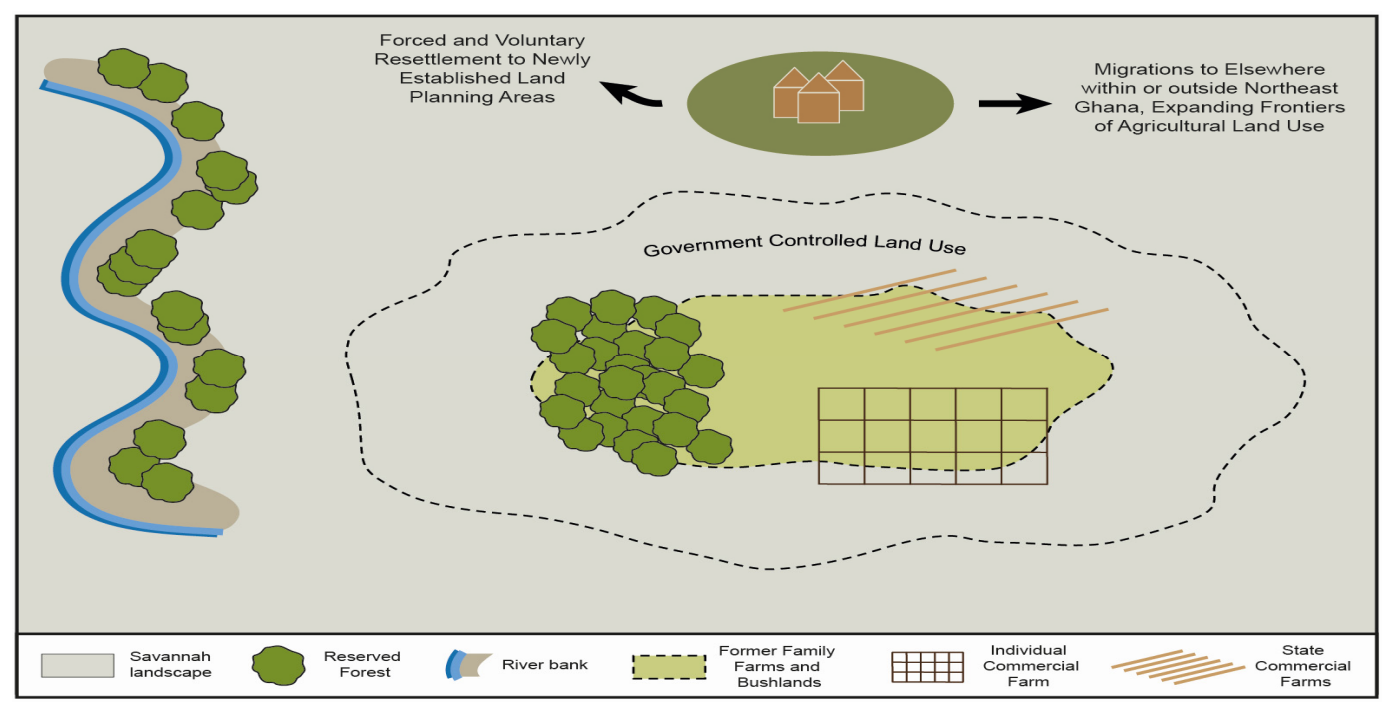

Figure 9. Patterns of Spatial Organisation and Changing Land Use during Colonial Period.

Riparian lands and other wooded areas also underwent some substantial changes. The colonial government's interest in land planning areas saw the establishment of forest reserves along streams/rivers and other wooded areas. The forest reserves were established in strategic locations to protect headwaters of important rivers/streams from siltation while supplying forestry products such as poles and lumber and to protect game and other wildlife. Non-indigenous tall tree species such as kapok, teak, and mahogany were especially planted in large numbers among widely interspersed indigenous savannah short trees such as shea trees and acacia. Establishment of forest reserves especially along riparian areas put a stop to the age old traditional practice of rice cultivation on floodplains and swamps around river/stream banks. By the end of the colonial period in 1957, there were more than thirty forest reserves in northeast Ghana, covering an area of approximately 2100 square kilometers. Many of the forest reserves established in the colonial period exist today, and one can clearly demarcate the boundary between non-indigenous tall tree species in the forest reserves from the surrounding indigenous short tree species.

\section{Discussion}

Upon British arrival in northeast Ghana in 1874, the sight of lone standing thickets or forest groves scattered over the landscape, the practise of shifting cultivation, use of fires to help clear farmland, and occasional bushfires were probably major factors that enforced their perception that 'wasteful' land use practises of the local people had deforested the and degraded the land. While such environmental crisis narratives were propagated by the British to justify the need for transformation of pre-colonial natural resource use/access regimes, their attempts to control land management matters were also for political and economic reasons. 
During the colonial era, the establishment of chieftaincy institutions through which the British indirectly governed the area had far reaching effects on pre-colonial land tenure arrangements and organisation of space around the tenets of traditional religious rules/practises supervised by the Tindaanas. Appointed chiefs and local 'big men' who could manipulate the system to their undue benefit bypassed the authority of the Tindaanas in land access and usage issues. Land could now be sold or leased for monetary rent, thus increasing the economic value of land such that there was scramble for private property rights in land often to the disadvantage of powerless peasants. The practice of approaching the Tindaanas for land for settlement and cultivation purposes seemed to fade as the British deliberately sought to dismantle the egalitarian system of land tenure around the authority of the Tindaanas. Dismantling the pre-existing egalitarian system of land tenure was embarked on by the British so that they could control land totally, strengthen their political authority, and roll out natural resource extraction and other commercial farming ventures to pay for the costs of running/administering the Protectorate. Through the enactment of various decrees and laws, the British colonial government acquired land where they promoted the large-scale cultivation of cash crops such as cotton, tobacco, rice, and vegetables, meaning that more unoccupied lands in the bush and around communities that were formerly devoted to staple food crop cultivation were now taken over by pseudo-capitalist farmers who cultivated cash crops. Increasing economic value of land and weakening authority of the Tindaana also meant that land allocated to native households for farming were reduced in size and in spatial extent, in comparison to the expansion of state commercial farms and increasing acquisition of land. Decreases in population through forced labour migration, later voluntary migration, and mortality through pests, diseases, and epidemics also contributed in reducing the frontiers or spatial extent of native farmlands at this period.

From the 1940s onwards, the colonial government's plan to transform the fortunes of agriculture in the northeast and to pursue land use planning for the benefit of the colonial state, had considerable effects on the organisation of space and mutations in land-use/cover patterns. First, mixed farming initiatives promoted by the government actively encouraged the expansion of individual land holdings. Many peasants dubbed 'wasteful' were also forcibly resettled to other newly created land planning areas. Many of the resettled peasants and individuals left their new villages and migrated to other areas in the hinterlands and other surrounding remote areas in the Northern Territories where colonial government influence and presence was less pronounced. These migrations effectively expanded the frontiers of agricultural land use as the new migrant settlers sought land from appropriate sources, established their compound settlements, and cultivated parcels of land around their compounds and in bushes for their livelihoods.

Riparian lands and other wooded areas also underwent some substantial changes. Forest reserves were established along streams/rivers and other wooded areas. The forest reserves were established in these strategic locations to protect headwaters of important rivers/streams from siltation while supplying forestry products such as poles and lumber and to protect game and other wildlife. Establishment of forest reserves especially along riparian areas put a stop to the age old traditional practice of rice cultivation on floodplains and swamps around river/stream banks. By the end of the colonial period in 1957, there were more than 30 forest reserves in northeast Ghana, covering an area of approximately 2100 square kilometers.

Successive post-independent governments have held on to the perception of the 'wasteful' and 'destructive' peasants, rolling out programmes to transform land tenure regimes for the reservation of forested land and expansion of a modernised capitalist commercial farming sector that will absorb excess peasant labour. For instance, the first post-independence government led by Kwame Nkrumah passed the State Lands Act of 1962, which mirrored the colonial Lands and Native Rights Ordinance of 1927 in that it granted powers to the state to appropriate any land it deemed fit to site development projects on [37]. Large parcels of suitably arable land were acquired in northeast Ghana for state-run large-scale mechanized farming. While this strategy was seen as the antidote to the country's recurrent problem of food shortages, rising food prices and inflation, and increasing 
wage bill for food imports [58], it was importantly seen as an avenue to tap the labour power of peasants whose practices such as shifting cultivation were perceived as destructive to the physical environment [50]. Some significant successes in food production were made in the first few years after implementing the large-scale modernised farming strategy, but the policy proved to be expensive and unsustainable in the long and plagued by corruption from government officials managing the state farms.

The conventional view on the farming practises of peasants has also influenced the design of land degradation policies outlined in the current policy document (i.e., Ghana NAP), which centres on the control/regulation/modernisation of economic and demographic behaviours of local resource users, with many indigenous land use practices regarded as 'irrational' [2,59]. The Ghanaian model of modernisation has been driven by input provision/support and limiting the expansion of subsistence farming into what they call 'marginal', 'fragile' or forested areas. While it is undisputed that adequate input and extension support provision is a critical ingredient for intensive land management, policy frameworks based merely on modernisation of farm practises have not taken into account the complex historical experiences of people who live within and work those landscapes, and how their dynamic activities shape land-use/cover dynamics over time. As Vadjunec et al. [60] argue, understanding the changes in smallholder land users' livelihoods from a critical historical perspective is very essential for comprehending changes in land use and land cover changes and how to manage those changes.

\section{Conclusions}

This paper discussed the evolution of and changes in socio-cultural and political relations that defined access to, use, and management of land resources in the savannahs of northeast Ghana during the pre-colonial and colonial periods. The aim was to historicise current meta-narratives about degradation of the natural landscape in the rural savannahs of northeast Ghana. A historical analysis of the origins of the 'indigenous degradation' and deforestation narrative in northern Ghana found that it was very common for colonial administrators in the nineteenth and early twentieth centuries to refer to thickets of vegetation distributed across the savannah landscape as remnants of a former forested landscape that has been degraded to a savannah state. As this study showed, it was not often the case that thickets of vegetation were remnants of former forests or that these thickets existed before permanent human settlements around where they are found. Traditional religious practices of the people required that such vegetation thickets be preserved and regarded highly as they are thought to be inhabited by protective ancestral spirits. The famous Gold Coast era anthropologist, A. W. Cardinal, also found in his many anthropological studies of the peoples and environment of northeast Ghana that many forest groves were once habitation sites of early settlers and the relatively richer vegetation were of fairly recent growth, growing up on land that was laden with evidence of middens that are rich in organic matter compared to the surrounding soils outside the thickets. Thus, groves or clusters of trees may have grown in areas where middens rich in organic nutrients, such as human and animal excreta and other organic remains of human habitation, may have enriched the soil and resulted in a thriving community of shrub and tree clusters over time. Cardinal reports that such tree vegetation thickets were later used as sacred groves upon revelation by local spiritualists that some ancestral spirits lived in such thickets. In this case of viewing the relationship between thickets and the direction of environmental change, the spatial and temporal framing of analysis by early colonial administrators were limited to using short-term observations in smaller areas to apply to larger areas, ignoring how early settlement, migration and culture for instance affect(ed) land-use/cover patterns.

Dryland management policy ought to move away from treating many indigenous land use and space management practices with suspicion and seeing a need to transform their mode of production as many 'modernisation' policies have done in the past. Policies that aim at sustainable agricultural growth and livelihoods security while maintaining functional wellbeing of ecosystem conditions must complement scientific knowledge with indigenous knowledge and participation of local natural resource users. Such a measure can enable reflection on the dynamic processes by which variations in 
socio-economic relations of resource access/use, farming practices, land tenure arrangements, and political agendas interacts with biophysical variability to produce different land-use/cover trajectories over time. This process starts with a paradigm shift towards working with the indigenous knowledge and participation of farmers and other land user who inhabit the areas. As this study shows, indigenous communities hold vast amounts of knowledge about the changing conditions of their socio-economic, political, and physical landscape, dating back to their ancestral occupations of the landscape. They also have complex systems of organising space and land use around the tenets of religious beliefs (e.g., sacred forest grove maintenance) and traditional practices adapted to changing conditions around them.

Acknowledgments: The author thanks Monash University for providing a generous Ph.D. scholarship which funded this research. Appreciation also goes to Haripriya Rangan, Christian Webersik, and Simon Batterbury for providing expert advice on preliminary drafts of this paper. Special thanks go to the staff at the Ghana Public Records and Archives Administration Department and other libraries where archival data was collected. Finally, the author also thanks the anonymous reviewers for providing constructive feedback. The usual disclaimer applies; all errors remain the author's own.

Conflicts of Interest: The author declares no conflict of interest.

\section{References}

1. Wardell, Andrew D. "Moving the Boundaries of Forest and Land Use History: the Case of Upper East Region in Northern Ghana." In Beyond Territory and Scarcity: Social, Cultural and Political Aspects of Conflicts on Natural Resource Management. Edited by Quentin Gausset, Michael A. Whyte and Torben Birch-Thomsen. Uppsala: Nordic Institute of African Studies, 2005.

2. Environmental Protection Agency. Ghana National Action Plan to Combat Drought and Desertification; Accra: Environmental Protection Agency, 2003.

3. Dickson, Kwamina B., and George Benneh. A New Geography of Ghana. London: Longman, 1970.

4. Korem, Andrew. Bush Fire and Agricultural Development in Ghana. Accra: Ghana Publishing Corporation, 1985, pp. 122-58.

5. Nsiah-Gyabaah, Kwasi. Environmental Degradation and Desertification in Ghana. Avebury: Ashgate, 1996.

6. Ministry of Lands and Forestry. Environmental Assessment of Northern Savanna Biodiversity Conservation Project (NSBCP) Draft; Accra: Ministry of Lands and Forestry, 2001. Available online: http://ghana.gov.gh/index.php/ blog-categories/blog-donec-eu-elit-in-nisi/94-ministries-info/378-ministry-of-lands-and-natural-resources (accessed on 11 September 2015).

7. Wagner, Michele. "Environment, Community and History: 'Nature in the Mind' In Nineteenth and Early Twentieth Century Buha, Western Tanzania." In Custodians of the Land: Ecology and Culture in the History of Tanzania. Edited by Gregory Maddox, James Giblin and Isaac Kimambo. London: James Currey, 1996.

8. Government of Ghana. “Upper East Region. " Available online: http://www.ghana.gov.gh/index.php/ about-ghana/regions/upper-east (accessed on 19 February 2013).

9. International Resources Group. Progress against Desertification: Case Studies of Experience in Ghana. Washington: United States Agency for International Development, 2005.

10. Yaro, Joseph A. "Is Deagrarianisation Real? A Study of Livelihood Activities in Rural Northern Ghana." The Journal of Modern African Studies 44 (2006): 125-56. [CrossRef]

11. Fortes, Meyer. The Dynamics of Clanship among the Tallensi: Being the First Part of an Analysis of the Social Structure of a Trans-Volta Tribe. London: Oxford University Press, 1945.

12. Adams, William Mark. Green Development: Environment and Sustainability in a Developing World, 3rd ed. London and New York: Routledge, 2009.

13. Blaikie, Piers, and Harold Brookfield, eds. Land Degradation and Society. London: Methuen, 1987.

14. Robbins, Paul. Political Ecology: A Critical Introduction, 2nd ed. Chichester and Oxford: Willey-Blackwell, 2004.

15. Escobar, Arturo. "After Nature: Steps to an Anti-Essentialist Political Ecology." Current Anthropology 40 (1999): 1-30. [CrossRef]

16. Zimmerer, Karl S., and Thomas J. Bassett, eds. Political Ecology: An Integrative Approach to Geography and Environment-Development Studies. New York: Guilford, 2003. 
17. Warren, Andrew, Simon Batterbury, and Henny Osbahr. "Soil Erosion in the West African Sahel: A Review and an Application of a Local Political Ecology Approach in South West Niger." Global Environmental Change 11 (2001): 79-95. [CrossRef]

18. Batterbury, Simon P. J., and Anthony J. Bebbington. “Environmental Histories, Access to Resources, and Landscape Change." Land Degradation \& Development 10 (1999): 279-89. [CrossRef]

19. Andersson, Elina, Sara Brogaard, and Lennart Olsson. "The Political Ecology of Land Degradation." Annual Review of Environment and Resources 36 (2011): 295-319. [CrossRef]

20. Lentz, Carola. Ethnicity and the Making of History in Northern Ghana. Edinburgh: Edinburgh University Press, 2006.

21. Wardell, Andrew D. "Collision, Collusion and Muted Resistance: Contrasting Early and Later Encounters with Empire Forestry in the Gold Coast, 1874-1957." In Collisions of Cultures and Identities: Settlers and Indigenous Peoples. Edited by Patricia Grimshaw and Russell McGregor. Melbourne: University of Melbourne Press, 2006, pp. 79-104.

22. Weiss, Holger. "Contested Historical and Geographical Narratives: Succession Disputes, Contested Land Ownership and Religious Conflicts in Northern Ghana." Studia Orientalia 101 (2007): 461-83.

23. Syme, John K. G. The Kusasis: A Short History. Accra: Ghana Public Records and Archives Administration Department, 1932, unpublished work.

24. Cleveland, David A. "Migration in West Africa: A Savanna Village Perspective." Africa: Journal of the International Africa Institute 61 (1991): 222-46. [CrossRef]

25. Rattray, Robert S. "The Tribes of the Ashanti Hinterland (Some Results of a Two-Year Anthropological Survey of the Northern Territories of the Gold Coast)." Journal of the Royal African Society 30 (1931): 40-57.

26. Cronon, William. Changes in the Land: Indians, Colonists, and the Ecology of New England. New York: Hill and Wang, 1983.

27. Cardinal, Allan W. The Natives of the Northern Territories of the Gold Coast: Their Customs, Religion, and Folklore. London: George Routledge and Sons, 1920.

28. Tonah, Steve. The Development of Agropastoral Households in Northern Ghana: Policy Analysis, Project Appraisal and Future Perspectives. Saarbrucken: Breitenbach, 1993.

29. Tonah, Steve. "Fulani Pastoralists, Indigenous Farmers and the Contest for Land in Northern Ghana." Afrika Spectrum 37 (2002): 43-60.

30. Tonah, Steve. "Chiefs, Earth Priests and the State: Irrigation Agriculture, Competing Institutions and the Transformation of Land Tenure Arrangements in Northeastern Ghana." In Contesting Land and Custom in Ghana: State, Chief and the Citizen. Edited by Janine M. Ubink and Kojo S. Amanor. Leiden: Leiden University Press, 2008, pp. 113-31.

31. Becher, Camila. "The Land Belongs to the Men: Land Access for Women in Northern Ghana as Part of Dynamic Transformation Processes." Ph.D. Thesis, Faculty of Sociology, University of Bielefeld, Bielefeld, Germany, 1996.

32. Adam, Jacques G. "Forested Relics and Savanna Species in the Area Pre-forest in Guinea." Bulletin of the French Botanical Society 95 (1948): 22-36. [CrossRef]

33. Fairhead, James, and Melissa Leach. Misreading the African Landscape: Society and Ecology in a Forest-Savanna Mosaic. Cambridge: Cambridge University Press, 1996.

34. Howell, Allison M. The Religious Itinerary of a Ghanaian People: The Kasena and the Christian Gospel. Frankfurt: Peter Lang Publications, 1994.

35. Arhin, Kwame. The Papers of George Ferguson: A Fanti Official of the Government of the Gold Coast, 1890-1897, 1st ed. Leiden: Afrika-Studiencentrum, 1974.

36. Bening, Raymond B. "Administration and Development in Northern Ghana." Ghana Social Science Journal 4 (1977): 58-76.

37. Laube, Wolfram. Actors, Structures and Institutional Change: External Interventions and the (De-) Institutionalization of Local Natural Resource Regimes in Northern Ghana. ZEF Development Studies Volume 4. Bonn: University of Bonn, 2007.

38. "Public Records and Archives Administration Department of Ghana." Accra, 2013.

39. Grischow, Jeff, and Holger Weiss. "Colonial Famine Relief and Development Policies: Towards an Environmental History of Northern Ghana." Global Environment 4 (2011): 50-97. [CrossRef] 
40. Bening, Raymond B. "Administrative Boundaries of Northern Ghana, 1898-1951." In Regionalism and Public Policy in Northern Ghana. Edited by Yakubu Saaka. New York: Peter Lang Academic Publishers, 2001.

41. Lentz, Carola. The Construction of Ethnicity: A Political History of North-West of Ghana from 1870 to 1990. Cologne: Rüdiger Koppe Verlag, 1998.

42. Nabila, John S. The Migration of the Fra-Fra in Northern Ghana: A Case Study of Cyclical Labor Migration in West Africa. East Lansing: Michigan State University, 1987.

43. Agbosu, Lewis K. “Land Administration in Northern Ghana." Review of Ghana Law 12 (1980): 104-33.

44. Lentz, Carola. "Is land inalienable? Historical and Current Debates on Land Transfers in Northern Ghana." Africa 80 (2010): 56-80. [CrossRef]

45. Phillips, Anne. The Enigma of Colonialism: British Policy in West Africa. London: James Currey, 1989.

46. Kasanga, Kasim, and Nii Ashie Kotey. Land Management in Ghana: Building on Tradition and Modernity. London: International Institute for Environment and Development, 2001.

47. Lund, Christian. "Who owns Bolgatanga? A Story of Inconclusive Encounters." In Land and the Politics of Belonging in West Africa. Edited by Richard Kuba and Carola Lentz. Leiden: Brill Publishers, 2005.

48. Ofori-Sarpong, Edward. "The Nature of Rainfall and Soil Moisture in the Northeastern Part of Ghana during the 1975-1977 Drought." Geografiska Annaler. Series A, Physical Geography 67 (1985): 186-98. [CrossRef]

49. Plange, Nii K. "The Colonial State in Northern Ghana: the Political Economy of Pacification." Review of African Political Economy 11 (1984): 29-43. [CrossRef]

50. Webber, Paul. "Agrarian Change in Kusasi, Northeast Ghana." Africa 66 (1996): 437-57. [CrossRef]

51. Der, Benedict. "Agricultural Policies in Northern Ghana during the Colonial Era." Universitas 8 (1987): 3-18.

52. Lynn, Charles W. "Agriculture in North Mamprusi: A Review of a Decade's Progress." Farm and Forest 3 (1942): 8-83.

53. Wardell, Andew D., Annette Reenberg, and Christian Tøttrup. "Historical Footprints in Contemporary Land Use Systems: Forest Cover Changes in Savannah Woodlands in the Sudano-Sahelian Zone." Global Environmental Change 13 (2003): 235-54. [CrossRef]

54. Wardell, Andrew D., and Christian Lund. "Governing Access to Forests in Northern Ghana: Micro-Politics and the Rents of Non-Enforcement." World Development 34 (2006): 1887-906. [CrossRef]

55. Dietz, Ton, David Millar, Saa Dittoh, Francis Obeng, and Edward Ofori-Sarpong. "Climate and Livelihood Change in North East Ghana." In The Impact of Climate Change on Drylands: With a Focus on West Africa. Edited by Ton Dietz, Ruerd Ruben and Jan Verhagen. Dordrecht: Kluwer Academic Publishers, 2004, pp. 149-72.

56. Munro, Paul G., and Greg Hiemstra-van der Horst. “Conserving Exploitation? A Political Ecology of Forestry Management in Sierra Leone." Australasian Review of African Studies 21 (2011): 59-72.

57. Lynn, Charles W. "Land Planning and Resettlement in the Northern Territories of the Gold Coast." Farm and Forest 7 (1946): 81-83.

58. Amanor, Kojo, Anthony Denkabe, and Kate Wellard. “Ghana: Country Overview.” In Non-Governmental Organisations and the State in Africa. Edited by Kate Wellard and James Copestake. London: Routledge, 1993, pp. 183-201.

59. Pabi, Opoku. “Understanding Land-Use/Cover Change Process for Land and Environmental Resources Use Management Policy in Ghana." GeoJournal 68 (2007): 369-83. [CrossRef]

60. Vadjunec, Jacqueline M., Claudia Radel, and Billie Lee Turner, II. "Introduction: The Continued Importance of Smallholders Today." Land 5 (2016): 34-42. [CrossRef]

(C) 2017 by the author. Licensee MDPI, Basel, Switzerland. This article is an open access article distributed under the terms and conditions of the Creative Commons Attribution (CC BY) license (http://creativecommons.org/licenses/by/4.0/). 